\title{
Impact of aging mechanism on model simulated carbonaceous aerosols
}

\author{
Y. Huang ${ }^{1}$, S. Wu ${ }^{2}$, M. K. Dubey ${ }^{3}$, and N. H. F. French ${ }^{4}$ \\ ${ }^{1}$ Department of Geological and Mining Engineering and Sciences, Michigan Technological University, \\ Houghton, MI 49931, USA \\ ${ }^{2}$ Atmospheric Science Program, Department of Geological and Mining Engineering and Sciences, Department of Civil and \\ Environmental Engineering, Michigan Technological University, Houghton, MI 49931, USA \\ ${ }^{3}$ Earth System Observations, Los Alamos National Laboratory, Los Alamos, NM 87545, USA \\ ${ }^{4}$ Michigan Tech Research Institute, Michigan Technological University, Ann Arbor, MI 48105, USA
}

Correspondence to: S. Wu (slwu@mtu.edu)

Received: 24 October 2012 - Published in Atmos. Chem. Phys. Discuss.: 9 November 2012

Revised: 2 June 2013 - Accepted: 3 June 2013 - Published: 4 July 2013

\begin{abstract}
Carbonaceous aerosols including organic carbon and black carbon have significant implications for both climate and air quality. In the current global climate or chemical transport models, a fixed hydrophobic-to-hydrophilic conversion lifetime for carbonaceous aerosol $(\tau)$ is generally assumed, which is usually around one day. We have implemented a new detailed aging scheme for carbonaceous aerosols in a chemical transport model (GEOS-Chem) to account for both the chemical oxidation and the physical condensation-coagulation effects, where $\tau$ is affected by local atmospheric environment including atmospheric concentrations of water vapor, ozone, hydroxyl radical and sulfuric acid. The updated $\tau$ exhibits large spatial and temporal variations with the global average (up to $11 \mathrm{~km}$ altitude) calculated to be 2.6 days. The chemical aging effects are found to be strongest over the tropical regions driven by the low ozone concentrations and high humidity there. The $\tau$ resulted from chemical aging generally decreases with altitude due to increases in ozone concentration and decreases in humidity. The condensation-coagulation effects are found to be most important for the high-latitude areas, in particular the polar regions, where the $\tau$ values are calculated to be up to 15 days. When both the chemical aging and condensation-coagulation effects are considered, the total atmospheric burdens and global average lifetimes of BC, black carbon, (OC, organic carbon) are calculated to increase by $9 \%$ (3\%) compared to the control simulation, with considerable enhancements of $\mathrm{BC}$ and $\mathrm{OC}$ concentrations in the Southern Hemisphere.
\end{abstract}

Model evaluations against data from multiple datasets show that the updated aging scheme improves model simulations of carbonaceous aerosols for some regions, especially for the remote areas in the Northern Hemisphere. The improvement helps explain the persistent low model bias for carbonaceous aerosols in the Northern Hemisphere reported in literature. Further model sensitivity simulations focusing on the continental outflow of carbonaceous aerosols demonstrate that previous studies using the old aging scheme could have significantly underestimated the intercontinental transport of carbonaceous aerosols.

\section{Introduction}

Carbonaceous aerosols, including both elemental carbon (EC) (also called black carbon, BC) and organic carbon (OC) (Chung and Seinfeld, 2002; Park et al., 2003) play important roles in affecting the climate directly and indirectly (Balkanski et al., 2010; Haywood and Boucher, 2000; Lohmann et al., 2000; Schulz et al., 2006). They also make significant contributions to particulate matter (PM), an important air pollutant in surface air (US Environmental Protection Agency (EPA), 2007). A recent assessment finds BC to be the second most important contributor to anthropogenic warming after carbon dioxide with a forcing of $1.1 \mathrm{~W} \mathrm{~m}^{-2}$ that has a large uncertainty of $90 \%$ (Bond et al., 2013). 
Major sources of carbonaceous aerosols include direct emissions from fossil fuel combustion, biomass and biofuel burning as well as photochemical oxidation of volatile organic compounds (VOCs). Fresh emitted or newly formed carbonaceous aerosols generally have low solubility (Kondo et al., 2007). However, various physical and chemical processes in the atmosphere can convert the hydrophobic carbonaceous aerosols to hydrophilic ones (Croft et al., 2005; Kanakidou et al., 2005; Liu et al., 2011). Globally it is estimated that wet scavenging provides the dominant sink for carbonaceous aerosols in the atmosphere (Chung and Seinfeld, 2002; Park et al., 2003). Since hydrophobic aerosols are more susceptible to wet scavenging, the conversion of carbonaceous aerosols from hydrophobic to hydrophilic ones can significantly affect the distribution and burden of carbonaceous aerosols in the atmosphere.

Global models for simulations of climate or atmospheric composition have generally assumed a simplified uniform lifetime $(\tau)$ for carbonaceous aerosols to convert from hydrophobic to hydrophilic ones, which is usually around 1 day (with a range of 1-2.5 days; see literatures in Table 1). Previous studies on the regional budget and intercontinental transport of carbonaceous aerosols have also used this simplified assumption (Fu et al., 2009; Heald et al., 2006; Liao et al., 2007; Park et al., 2003; Wang et al., 2011). Furthermore, aerosol transport models underestimate the observed global average $\mathrm{BC}$ measurements and suggest that the uniform lifetime treatment of $\mathrm{BC}$ aging may be contributing to this low bias (Bond et al., 2013).

On the other hand, recent chamber studies have shown that the aging of carbonaceous aerosols would be affected by local atmospheric environment such as ozone oxidation and water vapor inhibition (Pöschl et al., 2001), which implies that the hydrophobic to hydrophilic conversion rate would vary both spatially and temporally. In the study of Pöschl et al. (2001), the coating of soot particles by the oxidation of benzo(a)pyrene (BaP) with ozone leads to the particles' conversion from hydrophobic to hydrophilic, while water vapor serves as an inhibitor by competitive adsorption. In addition, physical processes, such as condensation and coagulation, also make important contributions to the aging of aerosols. The aging of soot particles by these processes at a polluted region is simulated by Riemer et al. (2004), with condensation of sulfuric acid onto the surface of soot particles dominant during daytime while coagulation being an important process during nighttime. The e-folding aging lifetimes are approximately $8 \mathrm{~h}$ below $250 \mathrm{~m}$ during daytime, with $2 \mathrm{~h}$ between $250 \mathrm{~m}$ and $3000 \mathrm{~m}$. During nighttime, the aging timescale was found to be $10-40 \mathrm{~h}$ on average. These aging timescales are further employed by Croft et al. (2005) in a global model to estimate the global lifetime and burden of BC. However, the parameterization for this scheme tends to strongly depend on the regional case that was chosen by Riemer et al. (2004), which is not appropriate for global model parameterization and thus could result in larger uncertainties at GCM scales. By contrast, Liu et al. (2011) proposed a new condensation-coagulation scheme to globally simulate the aging rate of $\mathrm{BC}$ by assuming it is proportional to the gas concentration of sulfuric acid that is produced from the oxidation of $\mathrm{SO}_{2}$ by hydroxyl radicals $(\mathrm{OH})$ in the ambient air. As a result, the lifetime of $\mathrm{BC}$ in the model is predicted to be temporally and spatially variable, which improved the model performance in terms of comparisons to surface observations as well as aircraft campaigns. Maria et al. (2004) reported observations that the average hydrophobic-to-hydrophilic conversion rate for organic aerosols was at least three times lower than the value widely used in climate models ( $\tau \sim 1$ day), which would potentially increase the burden of carbonaceous aerosols by $70 \%$ in climate models.

In this work, based on chamber study results from Pöschl et al. (2001), we first implement a new chemical oxidation aging mechanism for carbonaceous aerosols' hydrophobic to hydrophilic conversion in a chemical transport model, GEOS-Chem. We also follow Liu et al. (2011) to account for the condensation-coagulation aging effects. Finally, a combined aging scheme accounting for both the chemical oxidation and physical processes is applied in the model. Model simulation results for atmospheric carbonaceous aerosols with the updated aging mechanism are compared with observations of black carbon and organic carbon to evaluate the improvement in model performance over the standard version. The implications of this updated aging mechanism for model simulated global distribution, budgets, and long-range transport of carbonaceous aerosols are also examined with sensitivity studies.

\section{Approach and model descriptions}

We use the GEOS-Chem chemical transport model (CTM) (Bey et al., 2001), which is a global three-dimensional model driven by assimilated meteorological data from the Goddard Earth Observing System (GEOS) of the NASA Global Modeling Assimilation Office (http://acmg.seas.harvard.edu/ geos/index.html). We use GEOS-Chem v8-02-02 with resolution of $4^{\circ}$ latitude by $5^{\circ}$ longitude, and 47 vertical layers. GEOS-Chem contains a fully coupled Ozone- $\mathrm{NO}_{\mathrm{x}}-\mathrm{VOC}-$ Aerosol chemistry mechanism (Park et al., 2004). We run the model from June 2004 to December 2005, with year 2004 as spin-up runs and 2005 results for final analysis.

Anthropogenic emissions (including emissions from fossil fuel and biofuel combustion) for both $\mathrm{BC}\left(4.53{\left.\mathrm{Tg} \mathrm{C} \mathrm{yr}^{-1}\right)}^{-1}\right.$ and $\mathrm{OC}\left(9.33 \mathrm{Tg} \mathrm{C} \mathrm{yr}^{-1}\right)$ are based on Bond et al. (2007) for the year 2000. In the standard version of GEOS-Chem, freshly emitted $\mathrm{BC}$ and $\mathrm{OC}$ are treated as hydrophobic and hydrophilic components, with $80 \%$ hydrophobic BC and $50 \%$ hydrophobic OC (Chin et al., 2002; Cooke et al., 1999; Park et al., 2003; Wang et al., 2011). For biomass burning emission inventory, we use the Global Fire Emission 
Table 1. Model simulated global budgets of carbonaceous aerosols.

\begin{tabular}{|c|c|c|c|c|c|}
\hline Reference & $\begin{array}{l}\text { Aging } \\
\text { timescale }\end{array}$ & $\begin{array}{l}\text { BC lifetime } \\
\text { (days) }\end{array}$ & $\begin{array}{l}\text { BC burden } \\
(\mathrm{TgC})\end{array}$ & $\begin{array}{l}\text { OC lifetime } \\
\text { (days) }\end{array}$ & $\begin{array}{l}\text { OC burden } \\
(\mathrm{TgC})\end{array}$ \\
\hline $\begin{array}{l}\text { This study, with old aging } \\
\text { scheme }\end{array}$ & 1.15 days & 5.82 & 0.117 & 4.58 & 0.537 \\
\hline This study, with OXD & depends on $\left[\mathrm{O}_{3}\right],\left[\mathrm{H}_{2} \mathrm{O}\right]$ & 7.61 & 0.153 & 5.35 & 0.626 \\
\hline This study, with CC & depends on $[\mathrm{OH}]$ & 7.29 & 0.146 & 5.18 & 0.606 \\
\hline This study, with OCC & depends on $\left[\mathrm{O}_{3}\right],\left[\mathrm{H}_{2} \mathrm{O}\right],[\mathrm{OH}]$ & 6.31 & 0.127 & 4.70 & 0.551 \\
\hline This study, with TRIPLE & 3.45 days & 8.32 & 0.167 & 5.70 & 0.667 \\
\hline Mann et al. (2012) & microphysics & 4.76 & 0.100 & 4.59 & 0.87 \\
\hline Liu et al. (2011) & depends on $[\mathrm{OH}]$ & 9.5 & 0.20 & NA & NA \\
\hline Colarco et al. (2010) & 2.5 days & 8.82 & 0.174 & 6.9 & 0.929 \\
\hline Jacobson (2010) & microphysics & 4.7 & 0.127 & NA & NA \\
\hline Vignati et al. (2010) & microphysics & 6.2 & 0.14 & NA & NA \\
\hline Koch et al. (2009) & 1 day & 9.2 & 0.18 & NA & NA \\
\hline Liu et al. (2009) & 1.6 days & 5.8 & 0.17 & 5.3 & 0.83 \\
\hline Pierce et al. (2007) & 1.5 days & 8.48 & 0.19 & 4.80 & 0.80 \\
\hline Koch and Hansen (2005) & 1 day & 7.30 & 0.22 & NA & NA \\
\hline Liu et al. (2005) & microphysics & 3.3 & 0.12 & 3.2 & 0.98 \\
\hline Croft et al. (2005) & depends on $\left[\mathrm{O}_{3}\right],\left[\mathrm{H}_{2} \mathrm{O}\right]$ & 9.5 & 0.209 & NA & NA \\
\hline Easter et al. (2004) & microphysics & 5.9 & 0.16 & 5.5 & 0.99 \\
\hline Cooke et al. (2002) & 1.15 days & 4.29 & 0.06 & 3.39 & 0.13 \\
\hline Chin et al. (2002) & 1.2 days & 6.2 & 0.32 & 5.1 & 1.5 \\
\hline Chung and Seinfeld (2002) & 1.15 days & 6.4 & 0.22 & 5.3 & 1.2 \\
\hline Koch $(2001)$ & $\begin{array}{l}\text { depends on sulfate } \\
\text { production }\end{array}$ & 4.40 & 0.15 & 3.86 & 0.95 \\
\hline Cooke et al. (1999) & 1.15 days & $5.29 *$ & $0.073^{*}$ & $4.54^{*}$ & $0.087^{*}$ \\
\hline Cooke and Wilson (1996) & 1.6 days & 7.85 & 0.30 & NA & NA \\
\hline Liousse et al. (1996) & $\begin{array}{l}\text { depends on sulfate } \\
\text { production }\end{array}$ & 3.88 & 0.13 & NA & NA \\
\hline
\end{tabular}

* Only accounting for BC and OC from fossil fuel.

Database version 2 (GFED2) (van der Werf et al., 2006), with annual $\mathrm{BC}$ and $\mathrm{OC}$ emissions to be 2.80 and $21.98 \mathrm{Tg} \mathrm{C}$, respectively. Biogenic emissions of VOCs are calculated using the Model of Emissions of Gases and Aerosols from Nature (MEGAN) scheme (Guenther et al., 2006). Following Chin et al. (2002) and Park et al. (2003), we assume that there is around $10 \%$ of organic carbon aerosol yield (11.46 ${\mathrm{Tg} \mathrm{C} \mathrm{rr}^{-1}}^{-1}$ from terpines.

Dry deposition of aerosols in GEOS-Chem uses a standard resistance-in-series scheme from Wesely's model (Wesely, 1989; Wang et al., 1998). Wet scavenging follows the scheme used by Liu et al. (2001), including scavenging in convective updraft, rainout (in-cloud) and washout (belowcloud) from convective anvils and large-scale precipitation.

To investigate the sensitivity of model simulated carbonaceous aerosols to the chemical oxidation aging scheme, we firstly implement a new aging mechanism for carbonaceous aerosol's hygroscopic growth in the GEOS-Chem model based on results from a chamber study (Pöschl et al., 2001) to account for the oxidation of organic compounds by ozone while water vapor serves as inhibitor. With the same scheme as used by Tsigaridis and Kanakidou (2003), we im- plemented in GEOS-Chem the experiment-based formulation for the turnover rate from hydrophobic to hydrophilic, which is

$\tau_{\mathrm{OXD}}=\frac{1}{k_{\mathrm{OXD}}}=\frac{1+K_{\mathrm{O}_{3}}\left[\mathrm{O}_{3}\right]+K_{\mathrm{H}_{2} \mathrm{O}}\left[\mathrm{H}_{2} \mathrm{O}\right]}{K_{\infty} K_{\mathrm{O}_{3}}\left[\mathrm{O}_{3}\right]}$,

where $\tau_{\mathrm{OXD}}$ is the hydrophobic to hydrophilic conversion lifetime for carbonaceous aerosols; subscript OXD represents oxidation aging scheme; $k_{\mathrm{OXD}}$ is the rate coefficient for oxidation aging scheme; $\left[\mathrm{O}_{3}\right]$ and $\left[\mathrm{H}_{2} \mathrm{O}\right]$ are the concentrations for $\mathrm{O}_{3}$ and $\mathrm{H}_{2} \mathrm{O}$ in the atmosphere, respectively; $K_{\infty}$ is pseudo-first-order decay rate coefficient in the limit of high ozone concentrations, which is set to be $0.015 \mathrm{~s}^{-1}$ based on experiment data; $K_{\mathrm{O}_{3}}$ is the adsorption rate coefficient of $\mathrm{O}_{3}$ and $K_{\mathrm{H}_{2} \mathrm{O}}$ is the adsorption rate coefficient of $\mathrm{H}_{2} \mathrm{O}$, with experimentally optimized values of $2.8 \times 10^{-13}$ and $2.1 \times 10^{-17} \mathrm{~cm}^{3}$, respectively, which are given by

$K_{i}=\frac{S_{0, i} \omega_{i}}{4[\mathrm{SS}]_{\mathrm{S}}} \tau_{i}$,

where $S_{o, i}$ is the sticking coefficient of $\mathrm{O}_{3}$ and $\mathrm{H}_{2} \mathrm{O}$, with value $3.3 \times 10^{-3}$ and $0.4 \times 10^{-3}$, respectively; $\omega_{i}$ is the mean 
thermal velocity; $[\mathrm{SS}]_{\mathrm{S}}$ is the surface concentration of adsorption sites for the studied soot particles and measured to be $5.7 \times 10^{14}$ site $\mathrm{cm}^{-2} ; \tau_{i}$ is the mean residence time of $\mathrm{O}_{3}$ and $\mathrm{H}_{2} \mathrm{O}$ on particle surface sites, measured to be $5 \mathrm{~s}$ and $3 \times 10^{-3}$ s, respectively. Following Croft et al. (2005), we apply a physical shielding factor of 0.01 to account for the fact that the oxidized coating materials are not homogenously distributed on the surface of the aerosol.

Following Liu et al. (2011), the condensation-coagulation aging scheme is also investigated. The condensation of sulfuric acid gas onto the surface of particles leads to the conversion of carbonaceous aerosols from hydrophobic to hydrophilic. The conversion rate of particles by condensation is proportional to the sulfuric acid gas concentration, which is

$k_{\mathrm{CC}}=\left(D_{\mathrm{g}} M / \rho R \delta_{\mathrm{c}}\right) \cdot\left[\mathrm{H}_{2} \mathrm{SO}_{4}\right]_{\mathrm{g}}$,

where $k_{\mathrm{CC}}$ is the rate coefficient for condensationcoagulation aging scheme; subscript of $\mathrm{CC}$ represents condensation-coagulation; $\left[\mathrm{H}_{2} \mathrm{SO}_{4}\right]_{\mathrm{g}}$ is the gas concentration of $\mathrm{H}_{2} \mathrm{SO}_{4}$ in the air; $D_{\mathrm{g}}$ is the diffusivity of $\mathrm{H}_{2} \mathrm{SO}_{4}$ in the atmosphere; $M$ and $\rho$ are the molecular weight and particlephase density of $\mathrm{H}_{2} \mathrm{SO}_{4} ; R$ is the mass median radius of hydrophobic carbonaceous aerosols; $\delta_{\mathrm{c}}$ is the equivalent coating thickness for the carbonaceous aerosols to take the critical soluble mass into account.

The reaction of $\mathrm{SO}_{2}$ with $\mathrm{OH}$ produces $\mathrm{H}_{2} \mathrm{SO}_{4}$ in the air. The steady state concentration of $\mathrm{H}_{2} \mathrm{SO}_{4}$ in the air is derived as

$\left[\mathrm{H}_{2} \mathrm{SO}_{4}\right]_{\mathrm{g}}=\frac{k_{1}[\mathrm{OH}]\left[\mathrm{SO}_{2}\right]}{\sum_{i} 4 \pi D_{\mathrm{g}} r_{i}}$,

where $k_{1}$ is the reaction rate coefficient for $\mathrm{SO}_{2}+\mathrm{OH}$; [OH] and $\left[\mathrm{SO}_{2}\right]$ are gas concentrations of hydroxyl radicals and sulfur dioxide in the ambient air; $i$ represents each particle in the air and $r_{i}$ is the particle radius; $\sum_{i} r_{i}$ is the sum of all particle radiuses in each grid box. Combining Eqs. (3) and (4), we have

$k_{\mathrm{CC}}=\beta \cdot[\mathrm{OH}] \quad\left(\right.$ where $\left.\beta=\frac{k_{1} M\left[\mathrm{SO}_{2}\right]}{\sum_{i} 4 \pi R \delta_{\mathrm{c}} r_{i}}\right)$.

Taking coagulation effect into account, Eq. (5) becomes

$k_{\mathrm{CC}}=\beta \cdot[\mathrm{OH}]+\alpha$,

where $\beta$ and $\alpha$ are assumed to be constant, with values $4.6 \times 10^{-12} \mathrm{~cm}^{3}$ molecule $\mathrm{s}^{-1} \mathrm{~s}^{-1}$ and $5.8 \times 10^{-7} \mathrm{~s}^{-1}$. With a globally average concentration of $\mathrm{OH}$ of about $10^{6}$ molecules $\mathrm{cm}^{-3}, \beta$ is derived by assuming an e-folding aging time of 2.5 days; $\alpha$ is estimated by assuming e-folding lifetime for coagulation is 20 days.

With Eq. (6), we obtain

$\tau_{\mathrm{CC}}=\frac{1}{\beta \cdot[\mathrm{OH}]+\alpha}$,

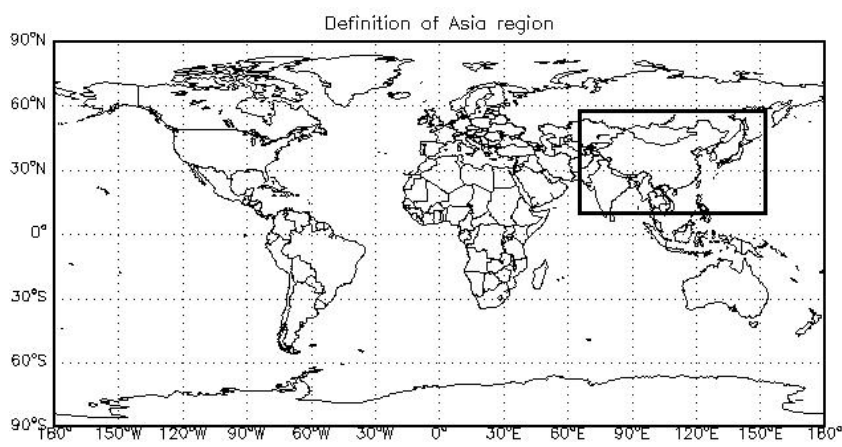

Fig. 1. Definition of Asia region for intercontinental transport study (longitude $63-150^{\circ} \mathrm{E}$ and latitude $10-58^{\circ} \mathrm{N}$ ).

where $\tau_{\mathrm{CC}}$ is the e-folding conversion lifetime from the condensation-coagulation scheme.

To consider the combined aging effects from oxidation and condensation-coagulation, the conversion rate is

$k_{\mathrm{OCC}}=\frac{1}{\tau_{\mathrm{OCC}}}=k_{\mathrm{OXD}}+k_{\mathrm{CC}}$,

where $k_{\mathrm{OCC}}$ and $\tau_{\mathrm{OCC}}$ are the rate coefficient and e-folding conversion lifetime for the combined aging scheme, respectively.

In addition to the control run using the a priori $\tau_{0}$ fixed at 1.15 days in the standard version of GEOS-Chem, we also carried out a sensitivity run by simply tripling the fixed conversion lifetime to 3.45 days (referred as TRIPLE). Results from the TRIPLE run are compared to the control run as well as the new aging schemes to offer an additional quick reference point for model simulations of carbonaceous aerosols.

The changes in carbonaceous aerosols' lifetime could have significant implications for the long-range transport of carbonaceous aerosols. To examine the potential impacts of the updated aging schemes on the intercontinental transport of carbonaceous aerosols, we set up sensitivity model runs where emissions of carbonaceous aerosols outside of the Asian region are turned off in the model. For the purpose of this study, we define the Asian region spanning longitudes 63 to $150^{\circ} \mathrm{E}$ and latitudes 10 to $58^{\circ} \mathrm{N}$, as shown in Fig. 1 . These sensitivity simulations allow us to evaluate and compare the continental outflow of carbonaceous aerosols from Asia with the old and updated aging schemes, respectively.

\section{Results}

\subsection{Impacts of the oxidation aging mechanism on model simulations of carbonaceous aerosol}

Figure 2a shows the hydrophobic to hydrophilic conversion lifetime $\tau$ for carbonaceous aerosol in surface air calculated with the oxidation aging mechanism. The longest lifetimes are found in the tropical areas, reflecting low ozone 


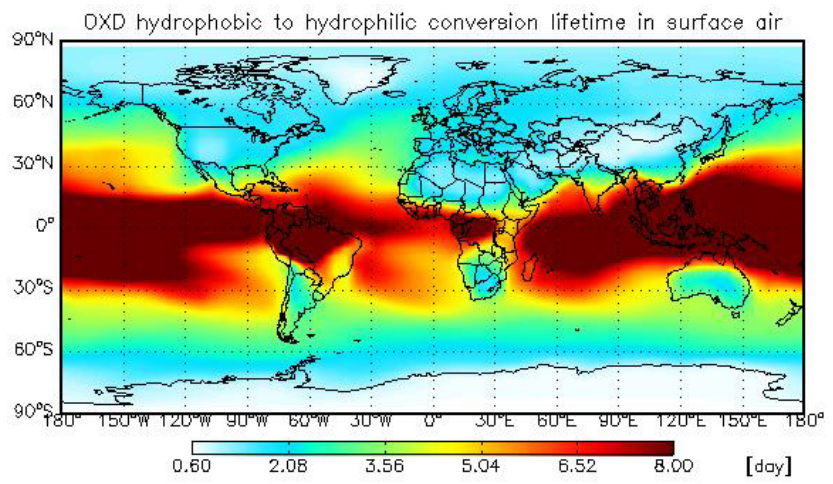

Fig. 2a. Model calculated hydrophobic to hydrophilic conversion lifetime for carbonaceous aerosols in surface air by oxidation aging scheme. OXD (hereinafter) represents oxidation aging scheme.

concentration and high humidity there, which is consistent with the simulation output by Tsigaridis and Kanakidou (2003). The global average value of $\tau$ is calculated to be around 4 days in surface air, which is significantly longer than the simplified parameter of 1.15 days as commonly used in contemporary atmospheric models (Fu et al., 2009; Heald et al., 2006; Liao et al., 2007; Park et al., 2003; Wang et al., 2011).

Figure $2 \mathrm{~b}$ shows the zonal mean plot for $\tau$, with the highest value found in the lower tropical troposphere. The lifetimes generally decrease with altitude, due to increases in ozone concentration and decreases in specific humidity with altitude. The global average value for $\tau$ is calculated to be approximately 3.1 days. Compared to the control runs, the decreased hydrophobic to hydrophilic conversion rates imply suppressed wet scavenging and hence increased atmospheric lifetimes of $\mathrm{BC}$ and $\mathrm{OC}$ with the oxidation aging mechanism. The global average lifetimes of $\mathrm{BC}$ and $\mathrm{OC}$ calculated with the oxidation aging mechanism (7.61 days for $\mathrm{BC}$ and 5.35 days for OC) are significantly higher than those calculated in the control simulation, by 31 and $17 \%$, respectively (Table 1). Consequently, the global burden of $\mathrm{BC}$ and $\mathrm{OC}$ are also found to be higher with the oxidation aging mechanism (by 31 and $17 \%$, respectively). The oxidation aging scheme also puts our calculated lifetime and burden of BC and OC on the high end in comparison to literature studies on carbonaceous aerosols (Table 1).

We examine the impacts of the oxidation aging scheme on model calculated surface BC concentrations in Fig. 3a. With the oxidation aging scheme, increases in surface $\mathrm{BC}$ concentrations by up to $0.16 \mu \mathrm{g} \mathrm{Cm}^{-3}$ are observed over South Asia, South America and African areas. These regions have high emissions of $\mathrm{BC}$ and also strong precipitation, which make the model simulated $\mathrm{BC}$ particularly sensitive to the aging mechanism used. The global burden of BC increased by almost $31 \%$ compared with the control run (Table 1). The ratio plot in Fig. 3a shows that the oxidation aging mechanism

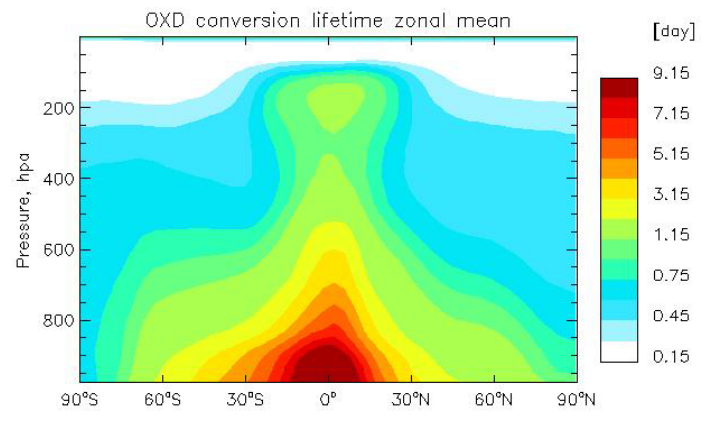

Fig. 2b. Zonal mean plot for hydrophobic to hydrophilic conversion lifetime for carbonaceous aerosol by oxidation aging scheme.
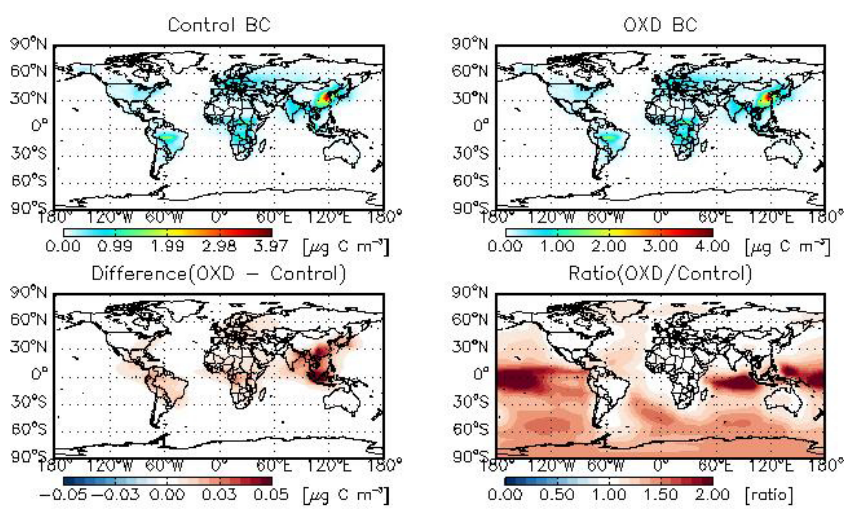

Fig. 3a. Model simulated annual mean surface BC concentrations from the sensitivity run versus the control run. (Upper left) BC concentrations from the control run; (upper right) $\mathrm{BC}$ concentrations from the sensitivity run using the oxidation aging scheme; (lower left) differences between the sensitivity run and control run results; (lower right) ratio between sensitivity run and control run results.

can lead to large increases in model simulated BC concentrations over the tropics and southern oceans with the surface $\mathrm{BC}$ concentrations over the tropics more than doubled.

Similar impacts are found on the model simulated OC concentrations with the oxidation aging mechanism (Fig. 3b). In particular, the highest concentration of surface OC concentration is predicted to increase by $0.67 \mu \mathrm{g} \mathrm{Cm}^{-3}$ over Asia, with the maximum ratio value up to 2.8 found over the tropical oceans. The global burden of OC concentration from oxidation aging scheme increases by almost $17 \%$ (Table 1), which implies more cooling effect of OC on climate forcing (Haywood and Boucher, 2000).

Global distributions of model simulated $\mathrm{BC}$ and $\mathrm{OC}$ are shown in zonal means in Fig. $3 \mathrm{c}$ and d, respectively. For BC (Fig. 3c), the highest concentrations are found over the northern midlatitudes near the surface due to the $\mathrm{BC}$ sources from combustion of fossil fuel, with a second peak happening near the tropics, indicating the importance of biomass burning (Chung and Seinfeld, 2002; Ramanathan and Carmichael, 2008). With the oxidation aging 

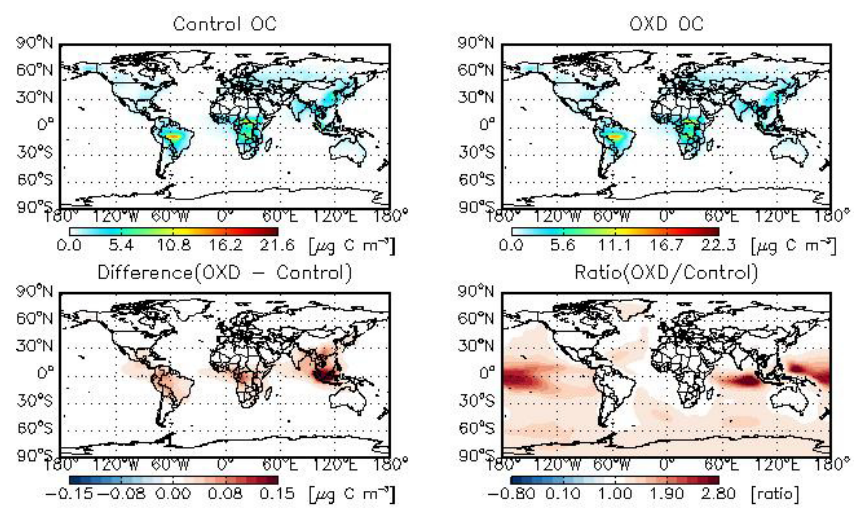

Fig. 3b. Same as Fig. 3a but for OC.
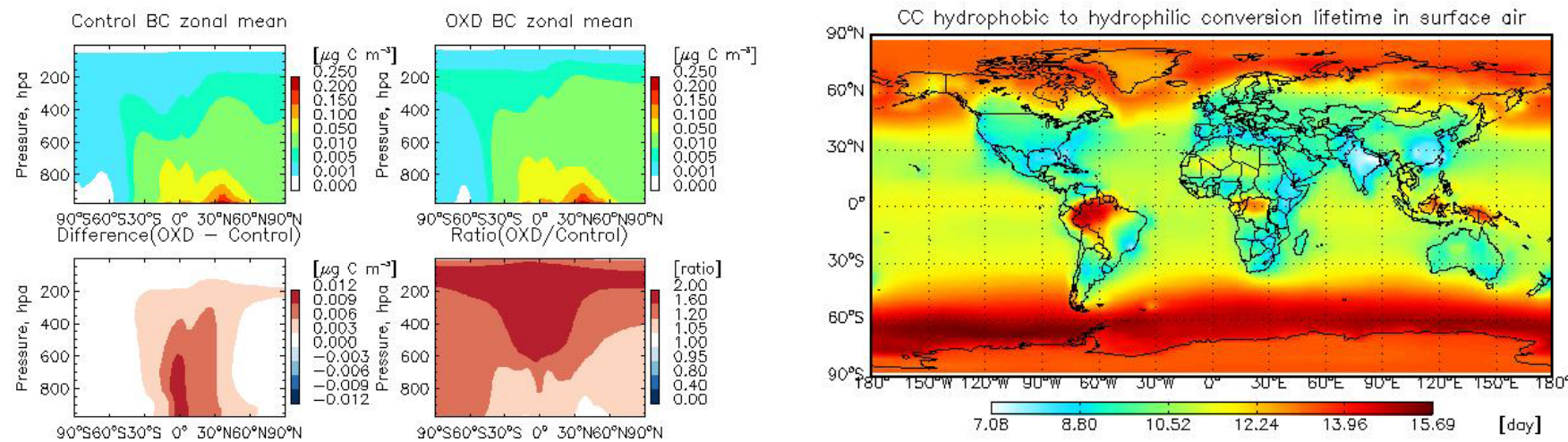

Fig. 3c. Same as Fig. 3a but for zonal mean.

mechanism, the concentrations of $\mathrm{BC}$ increase by more than $20 \%$ in the middle and upper atmosphere, with the largest perturbations found in the upper atmosphere (more than double). The strongest perturbations to model simulated OC with the oxidation aging scheme are found over the tropics (Fig. 3d), reflecting the strong sources of OC from biomass burning and biogenic emissions. OC concentrations in the tropical upper troposphere are calculated to increase by a factor of 4 with the oxidation aging scheme.

\subsection{Impacts of the condensation-coagulation aging mechanism on model simulations of carbonaceous aerosol}

The $\tau$ values calculated using the condensation-coagulation aging scheme strongly depend on the distributions of $\mathrm{OH}$ concentrations. Due to the low concentrations of $\mathrm{OH}$ at high latitudes, the longest $\tau$ values are found over the polar regions (Fig. 4a), which is consistent with the findings by Liu et al. (2011). High $\tau$ values are also found in the Amazon region, South Asia and West Africa. Compared to the control simulation, the $\tau$ values at the northern midlatitudes are generally increased by more than 4 times, implying lower aging rates for primary carbonaceous aerosols from the an-

Fig. 4a. Model calculated hydrophobic to hydrophilic conversion lifetime for carbonaceous aerosols in surface air by condensation-coagulation aging scheme. CC (hereinafter) represents condensation-coagulation aging scheme.

thropogenic emissions and more hydrophobic aerosols existing in the atmosphere. Figure $4 \mathrm{~b}$ shows the zonal mean plot for $\tau$ values with the lowest values found in the tropical upper troposphere, reflecting the high $\mathrm{OH}$ concentration there. Overall, this aging scheme leads to $25 \%$ increases in the global atmospheric burden $(0.146 \mathrm{Tg})$ and lifetime (7.29 days) of BC when compared with the control simulation (Table 1). The global burden of atmospheric OC is $0.607 \mathrm{Tg}$, with lifetime of 5.18 days, which increases by $13 \%$ from the control runs. As discussed in Sect. 3.1, the oxidation aging scheme increases the burdens and lifetimes of BC and OC, compared with the condensation-coagulation aging scheme, implying lower aging efficiency.

With the condensation-coagulation aging scheme, model simulated surface BC concentrations are shown in Fig. 5a. Compared with the control run, increases BC concentrations are observed over South America, South Africa, southeastern Asia and high latitudes of the North Hemisphere, by up to $0.05 \mu \mathrm{g} \mathrm{Cm}^{-3}$. Ratio plot shows that this aging scheme increases the BC surface concentrations at both Poles by over a factor of 2. Similar impacts are found for model simulated 


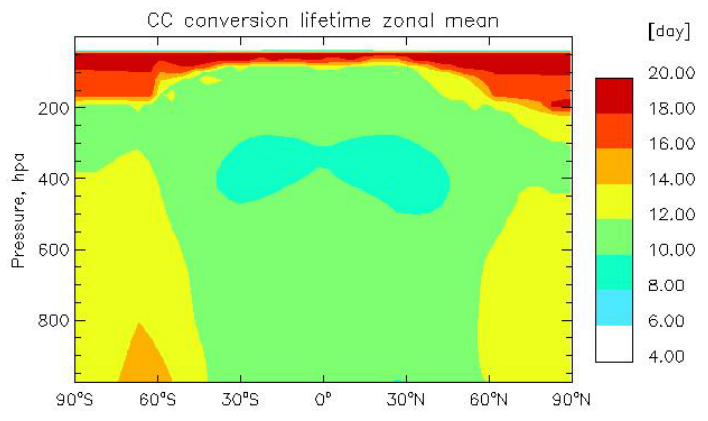

Fig. 4b. Zonal mean plot for hydrophobic to hydrophilic conversion lifetime for carbonaceous aerosol by condensation-coagulation aging scheme.
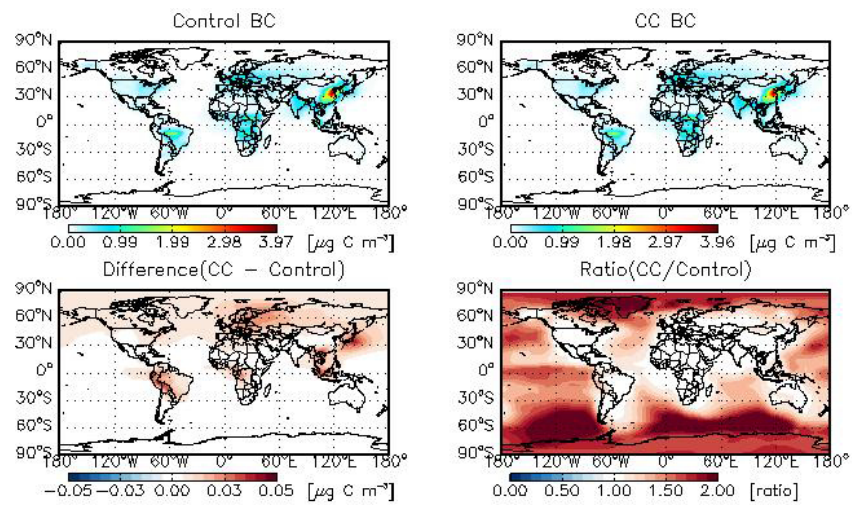

Fig. 5a. Model simulated annual mean surface $B C$ concentrations from the sensitivity run versus the control run. (Upper left) BC concentrations from the control run; (upper right) $\mathrm{BC}$ concentrations from the sensitivity run using the condensation-coagulation aging scheme; (lower left) differences between the sensitivity run and control run results; (lower right) ratio between sensitivity run and control run results.

OC concentrations in surface air, with largest increases by up to $0.25 \mu \mathrm{g} \mathrm{Cm}^{-3}$ over South America, South Africa and South Asia (Fig. 5b). Ratio plot shows that OC surface concentrations at remote regions increase by a factor of 1.7.

Global zonal mean plots for $\mathrm{BC}$ and $\mathrm{OC}$ are shown in Fig. $5 \mathrm{c}$ and d, respectively. They reflect that the concentrations of $\mathrm{BC}$ and $\mathrm{OC}$ at the Arctic regions are significantly strengthened, which means that the burdens of carbonaceous aerosols in the Arctic is larger than the control runs and the magnitude of the impact of anthropogenic emissions from lower latitudes on the Arctic is larger, compared with the control runs. This is justified by global models, which always underestimate the carbonaceous aerosols against aircraft campaigns as well as long-term surface observations (Chung and Seinfeld, 2002; Heald et al., 2011; Wang et al., 2011; Liu et al., 2011). Similar to the oxidation aging scheme, OC concentrations at the tropical regions are strengthened due to strong emissions of biomass burning as well as biogenic emissions there. Strongest perturbations to simulated BC and
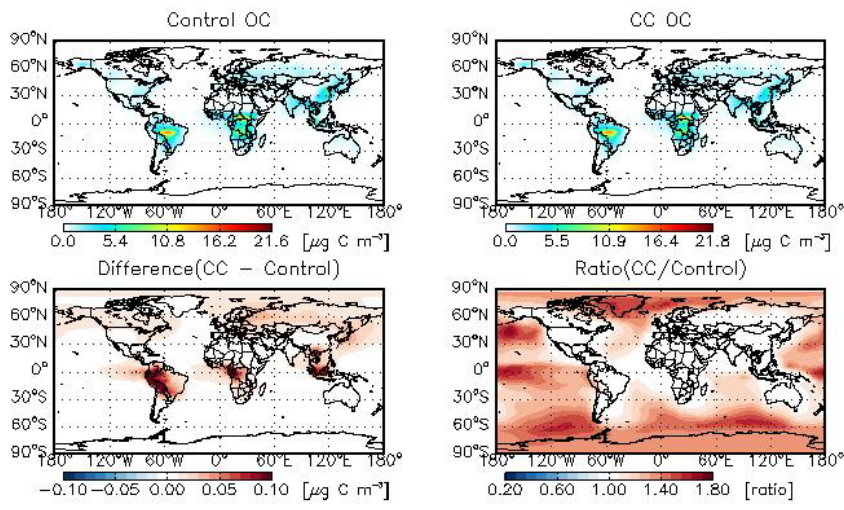

Fig. 5b. Same as Fig. 5a but for OC.

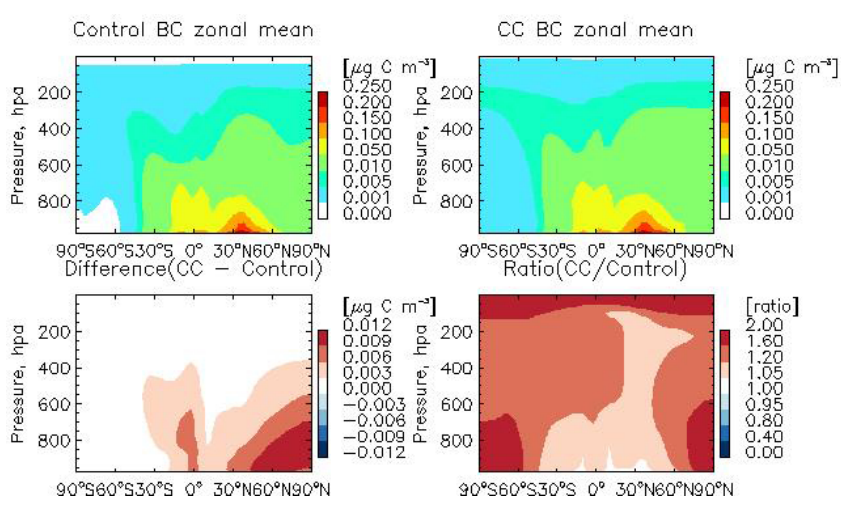

Fig. 5c. Same as Fig. 5a but for zonal mean.

OC are found at the Arctic and Antarctic regions as well as upper troposphere by a factor of $2-4$.

\subsection{Impact of the combined and TRIPLE aging schemes}

The combined aging scheme accounts for both the chemical oxidation and the physical condensation-coagulation aging. With the combined aging scheme, global burdens of BC and $\mathrm{OC}(0.127 \mathrm{Tg}$ for $\mathrm{BC}$ and $0.551 \mathrm{Tg}$ for $\mathrm{OC})$ are found to be slightly higher than the control simulation by 9 and $3 \%$, with global average $\mathrm{BC}$ and $\mathrm{OC}$ lifetimes to be 6.31 and 4.70 days, respectively (Table 1).

Compared with the control runs, surface concentrations of $\mathrm{BC}$ and $\mathrm{OC}$ in Chinese regions decrease by up to 0.06 and $0.16 \mu \mathrm{g} \mathrm{Cm}^{-3}$, while increase by up to 0.02 and $0.06 \mathrm{\mu} \mathrm{Cm}^{-3}$ in southeastern Asia and South America, respectively (Fig. 6a and b). The ratio plots in Fig. 6a, b show that the percentage changes of surface $\mathrm{BC}$ and $\mathrm{OC}$ concentrations are within 20 and $15 \%$, with negative change in remote areas of the Northern Hemisphere and positive change in remote regions of the Southern Hemisphere, compared with the control runs. Figure $6 \mathrm{c}$ and d show the combined aging scheme leads to decreased model simulated BC and OC in the troposphere of the Northern Hemisphere by up to 0.005 


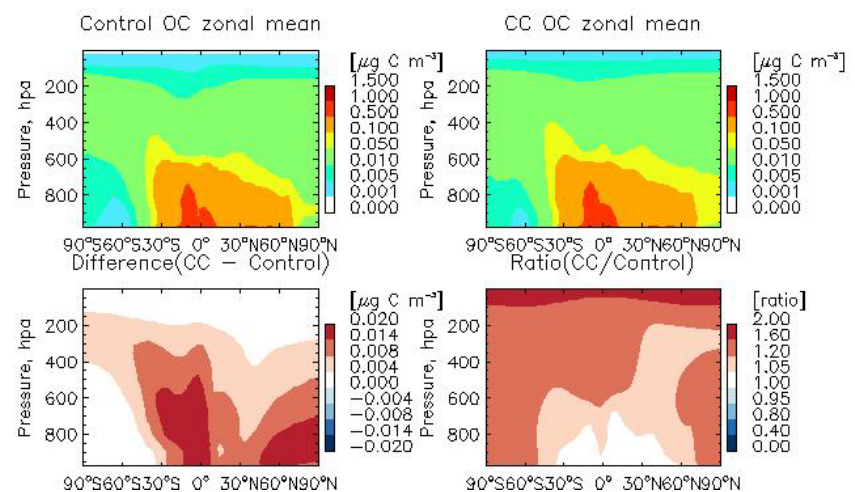

Fig. 5d. Same as Fig. 5b but for zonal mean.
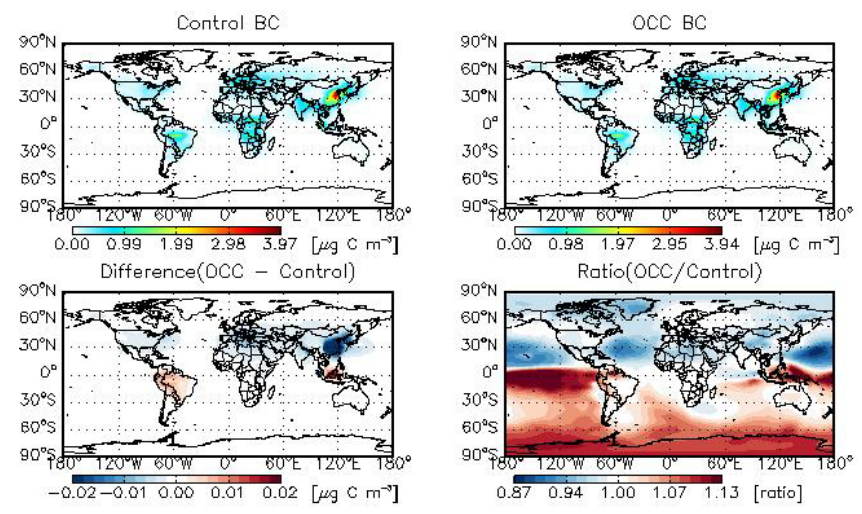

Fig. 6a. Model simulated annual mean surface BC concentrations from the sensitivity run versus the control run. (Upper left) BC concentrations from the control run; (upper right) $\mathrm{BC}$ concentrations from the sensitivity run using the combined aging scheme; (lower left) differences between the sensitivity run and control run results; (lower right) ratio between sensitivity run and control run results. OCC (hereinafter) represents the combined aging scheme.

and $0.007 \mu \mathrm{g} \mathrm{m}^{-3}$. In contrast, the model simulated BC and OC concentrations increase in the Southern Hemisphere. The hydrophobic-to-hydrophilic conversion lifetimes calculated with the combined aging scheme are generally higher in the Southern Hemisphere than the Northern Hemisphere.

With the TRIPLE aging scheme, the global average atmospheric lifetimes of $\mathrm{BC}$ and $\mathrm{OC}$ (8.32 days for $\mathrm{BC}$ and 5.70 days for $\mathrm{OC}$ ), similar to the results from the combined aging scheme, are significantly higher than those calculated in the control simulation, by 43 and $24 \%$, respectively (Table 1). Meanwhile, BC and OC burdens are calculated to be 0.167 and $0.667 \mathrm{Tg}$, which are higher than the oxidation, condensation-coagulation and combined aging schemes.

We examine the impacts of the TRIPLE aging scheme on model simulated surface BC concentrations in Fig. 7a. Increases of surface $\mathrm{BC}$ concentrations are found to be at the source regions by up to $0.19 \mu \mathrm{g} \mathrm{Cm}^{-3}$. Ratio plot shows that largest perturbations are observed at remote areas (more than double), which implies the importance of the long-
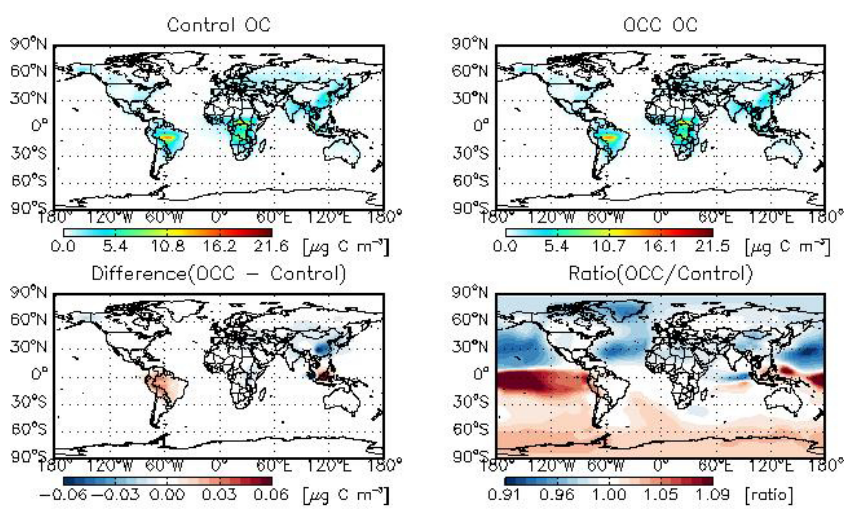

Fig. 6b. Same as Fig. 6a but for OC.

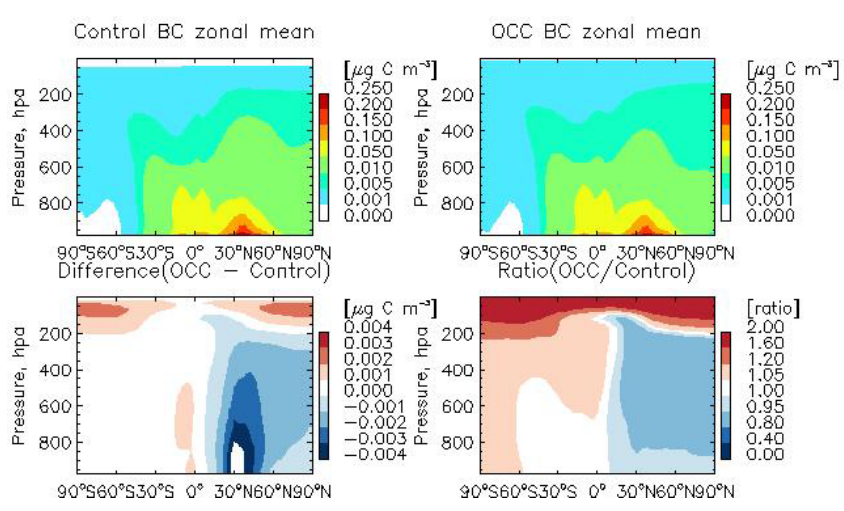

Fig. 6c. Same as Fig. 6a but for zonal mean.

range transport. Similar results are found for model calculated global OC surface concentrations (Fig. 7b), with the largest increases found to be $0.85 \mathrm{\mu g} \mathrm{Cm}^{-3}$ in South Asia, which implies that model performance is highly sensitive to the $\tau$ values at source regions.

With the TRIPLE aging scheme, global distributions of model simulated BC and OC are shown in Fig. 7c and d, respectively. $\mathrm{BC}$ and $\mathrm{OC}$ concentrations, in the lower troposphere of the Northern Hemisphere, are found to increase by up to 0.018 and $0.058 \mathrm{\mu g} \mathrm{m}^{-3}$, respectively, with the largest perturbations found in the upper troposphere for both $\mathrm{BC}$ and OC (more than double).

\subsection{Comparison with observations}

Ground-based Interagency Monitoring of Protected Visual Environments (IMPROVE) observational data in 2005 (http: //views.cira.colostate.edu/web/), surface observations from China Atmosphere Watch Network (CAWNET) in 2006 (Zhang et al., 2008) and the BC/OC campaign during 20022003 in Europe by the European Monitoring and Evaluation Programme (EMEP) (http://www.nilu.no/projects/ccc/ emepdata.html) are employed to evaluate the global carbonaceous aerosol simulation results from the control run and 


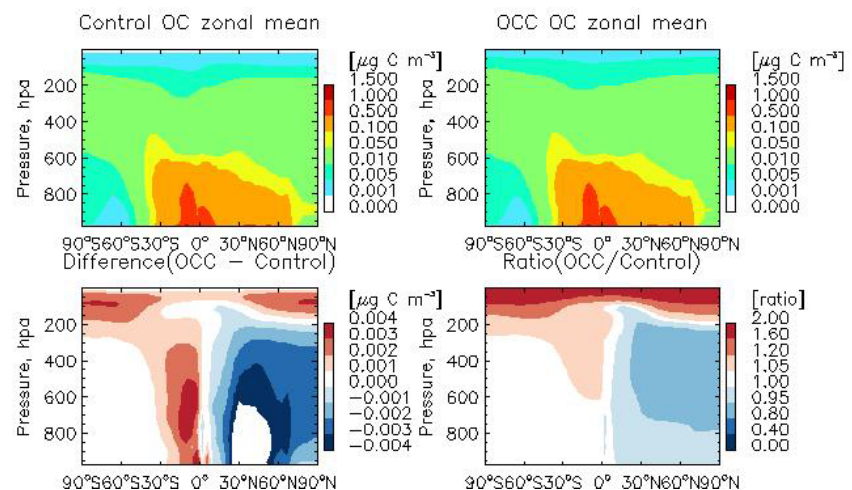

Fig. 6d. Same as Fig. 6b but for zonal mean.
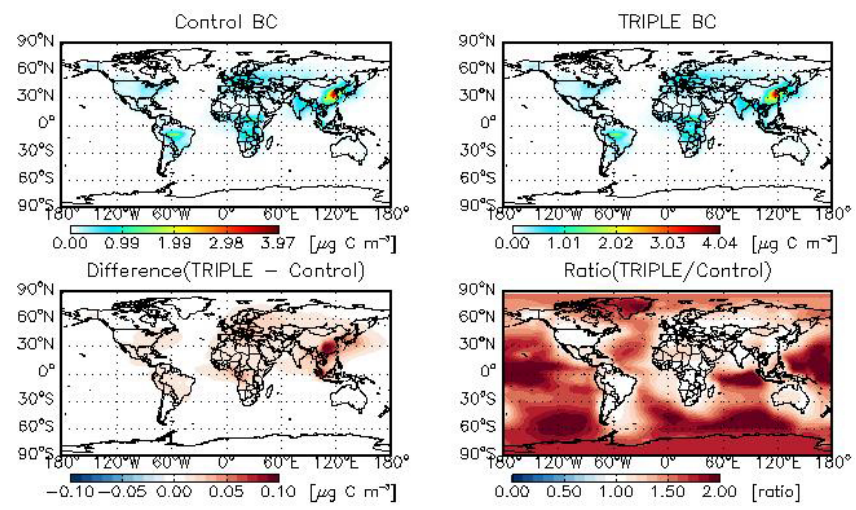

Fig. 7a. Model simulated annual mean surface BC concentrations from the sensitivity run versus the control run. (Upper left) $\mathrm{BC}$ concentrations from the control run; (upper right) $\mathrm{BC}$ concentrations from the sensitivity run using the TRIPLE aging scheme; (lower left) differences between the sensitivity run and control run results; (lower right) ratio between sensitivity run and control run results.

updated aging scheme simulations. For the purpose of comparison to measurements, we treat $\mathrm{BC}$ equivalent to $\mathrm{EC}$ in this study although different measurement techniques, such as thermal technique for $\mathrm{EC}$ and photo-absorption for $\mathrm{BC}$, could sometimes result in significant mass concentration differences (Jeong et al., 2004). Observational sites from these three observational networks are shown in Fig. 8. We use the annual mean data for BC and OC in 2005 to compare with observations by assuming that the interannual variability is small. Additionally, we use aircraft campaigns, Asian Pacific Regional Aerosol Characterization Experiment (ACE-Asia) in April 2001 (Huebert et al., 2004) and the first deployment of Hiaper Pole-to-Pole Observations (HIPPO1) (http: //hippo.ucar.edu) in January 2009 (Schwarz et al., 2010), to compare with the vertical distributions of model calculated carbonaceous aerosols by the above aging schemes.

Surface concentrations of BC and OC from models and selected sites of IMPROVE are shown in Fig. 9a and b. Annual mean $\mathrm{BC}$ and $\mathrm{OC}$ from control simulations are generally
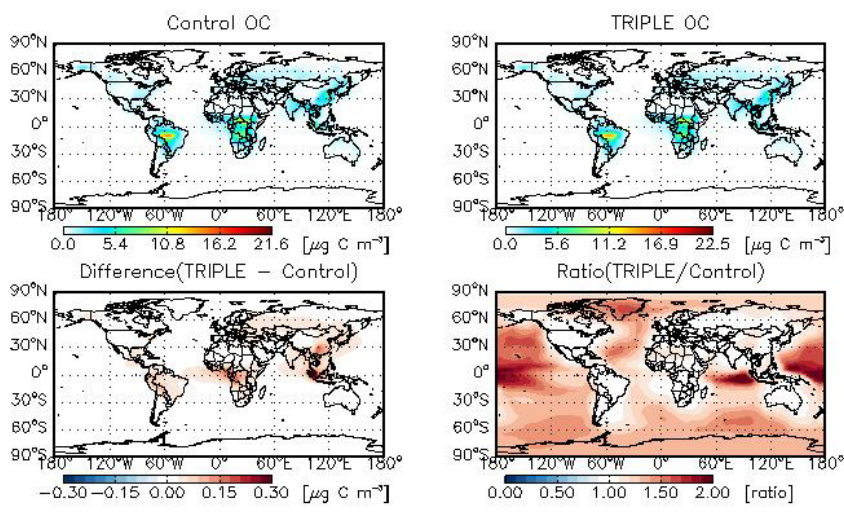

Fig. 7b. Same as Fig. 7a but for OC.

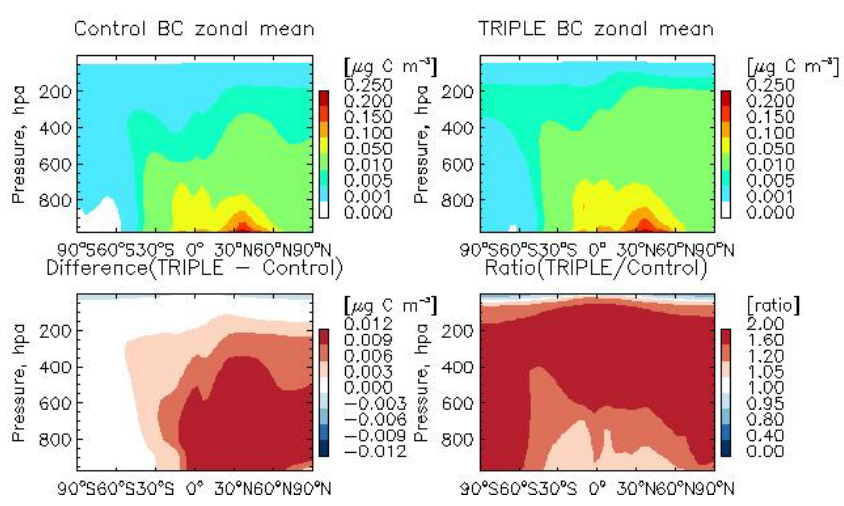

Fig. 7c. Same as Fig. 7a but for zonal mean.

underestimated by a factor of 2, which are consistent with other model findings (Park et al., 2003; Liu et al., 2011). With the updated aging schemes, model simulated BC and OC improve the underestimate within a factor of 1.5 , except the combined aging scheme. The comparisons of BC surface concentrations against observations from EMEP are shown in Fig. 9a. The model generally captures well BC concentrations, except at four sites located in Italy, Belgium, Portugal and Great Britain. Without these four sites, our updated aging schemes, especially the TRIPLE aging scheme, almost bring model simulated $\mathrm{BC}$ equal to observations. By contrast, the control simulation largely underestimates $\mathrm{OC}$ (more than 6 times), even the updated aging schemes (except the combined aging scheme) only slightly improve the model performance within a factor of 6 (Fig. 9b). This can be explained that open fire emissions are probably underestimated by the model emission inventory because open fires are the dominant source of OC. The scenario is even worse at the CAWNET of China. The control simulation significantly underestimates BC and $\mathrm{OC}$ by a factor of 7 and 16 , respectively (Fig. 9a, b). This is mainly due to the underestimates of anthropogenic emissions and seasonal fire activities in South Asia (Wang et al., 2011). Wang et al. (2011) doubled the anthropogenic emissions in Asia but still got a low bias 


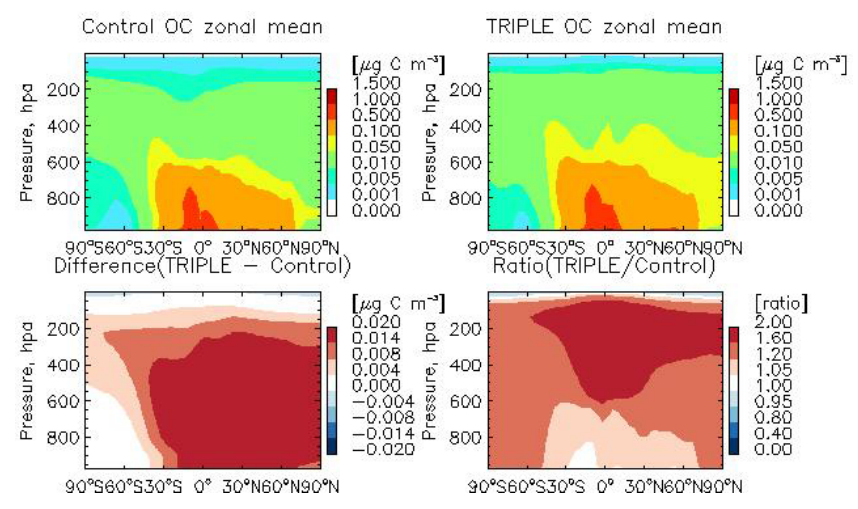

Fig. 7d. Same as Fig. 7b but for zonal mean.

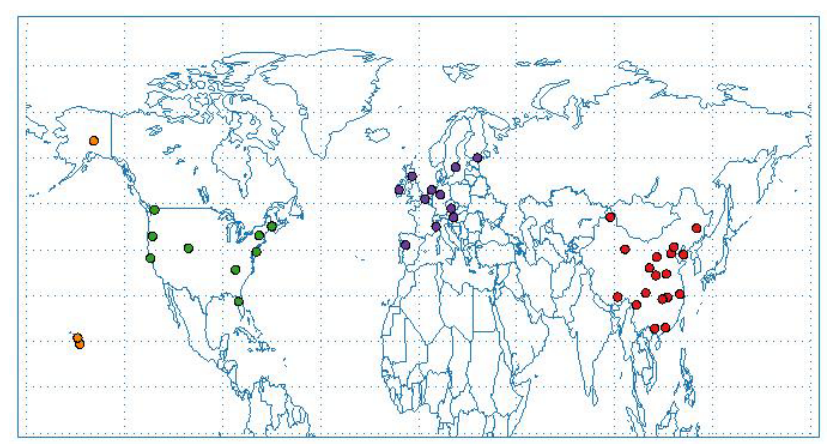

Fig. 8. Observational sites from CAWNET (red circles), EMEP (purple circles) and IMPROVE (green circles). Remote sites HAVO, HALE and DENALI are from IMPROVE with orange circles.

of model simulated BC, compared with CAWNET observations. This implies that the anthropogenic emission sources in China should be more than double.

Model simulated BC and OC concentrations in surface air at three remote sites are compared with observational data from the IMPROVE network: the Hawaii Volcanoes National Park (HAVO) $\left(19.4^{\circ} \mathrm{N}, 155.3^{\circ} \mathrm{W}\right)$, the Haleakala National Park (HALE) $\left(20.8^{\circ} \mathrm{N}, 156.3^{\circ} \mathrm{W}\right)$ and Denali National Park (DENALI) $\left(63.7^{\circ} \mathrm{N}, 149^{\circ} \mathrm{W}\right)$. The annual mean concentrations of BC and OC for 2005 are used in the comparison. Compared to the control run, the simulation with oxidation aging scheme increases the annual mean concentration of $\mathrm{BC}$ and OC at HAVO by approximately 38 and $30 \%$, respectively (Fig. 9a, b). The TRIPLE aging scheme increases the simulated BC and OC concentrations by 80 and $59 \%$, respectively, compared to the control run, leading to the best agreement with observations. The TRIPLE aging considerably improves the model performance, although it still underestimates the observations by a factor of 2 . Identifying the causes for the remaining model underestimates of carbonaceous aerosols is beyond the scope of this study, but one likely source for OC that is missing in our model is sea salt. It has been reported that there are around $10 \%$ of sea salt aerosols containing organic compounds during the

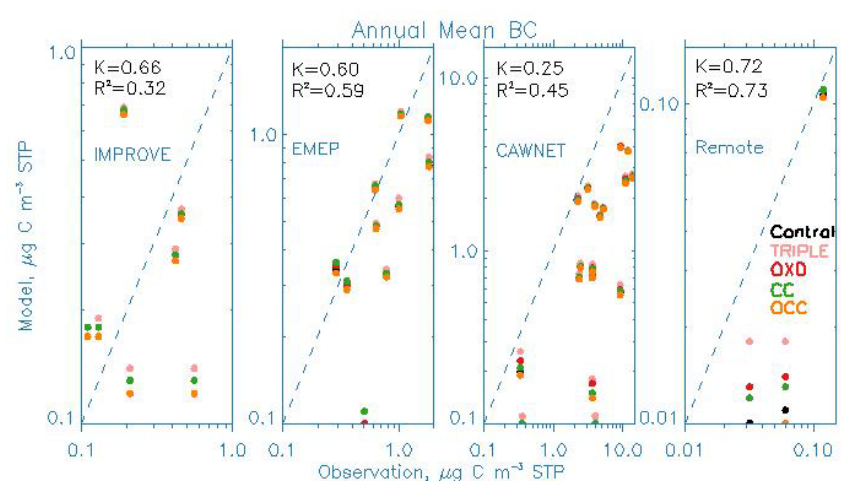

Fig. 9a. Scatter plots for annual mean BC between model simulation results and observations from IMPROVE, EMEP, CAWNET and remote sites. Black circles represent control simulation results, with TRIPLE, oxidation, condensation-coagulation and combined aging schemes are shown by purple, red, green and orange circles, respectively. Slope $(K)$ and correlation coefficients $\left(R^{2}\right)$ between observation and control simulation are shown in each panel.

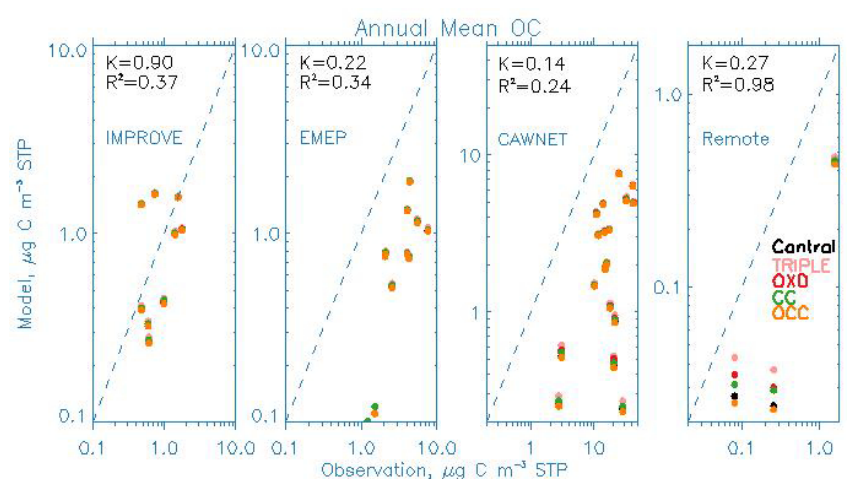

Fig. 9b. Same as Fig. 9a but for OC.

First Aerosol Characterization Experiment (ACE 1) by analyzing the composition of marine particles under various environmental conditions (Middlebrook et al., 1998). Cavalli et al. (2004) reported even higher fraction of organic compounds in marine aerosols during a phytoplankton bloom period in the North Atlantic, with 54 and $4 \%$ of organic compounds in marine aerosols under submicron and supermicron modes, respectively. Global models estimate that the marine OC emission source is around $8-9 \mathrm{Tg} \mathrm{Cyr}^{-1}$ (Meskhidze et al., 2011; Spracklen et al., 2008), which is further con-

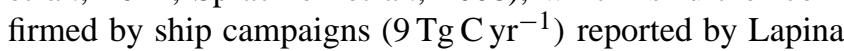
et al. (2011).

The model simulated vertical profiles of $\mathrm{BC}$ and $\mathrm{OC}$ are compared against observations from the aircraft campaign ACE-Asia in April 2001 (Huebert et al., 2004) in Fig. 10. With the TRIPLE aging scheme, model simulated $\mathrm{BC}$ and $\mathrm{OC}$ are found to increase by $\sim 64$ and $\sim 45 \%$ respectively, from the control run at 4-6 km altitude. By contrast, model simulated $\mathrm{BC}$ and $\mathrm{OC}$ with the oxidation aging 


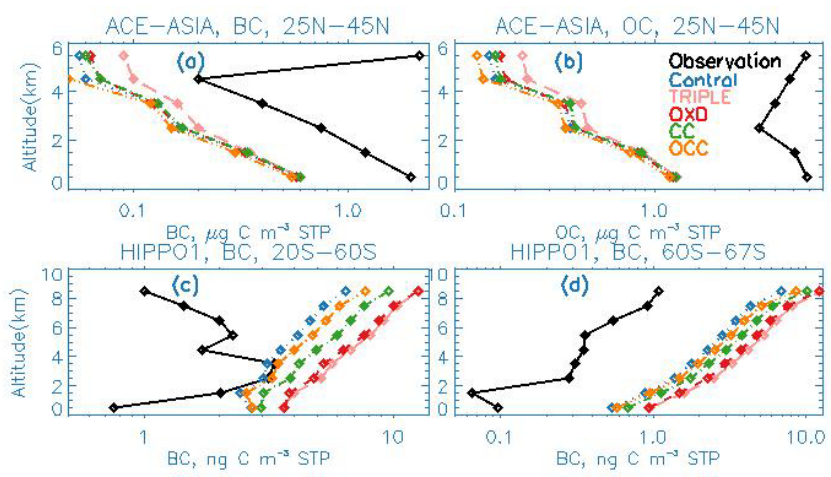

Fig. 10. Vertical profiles of $B C$ and $O C$ from model simulations and aircraft campaigns. (a) BC from NSF/NCAR C-130 aircraft campaign in ACE-Asia (latitude $25-45^{\circ} \mathrm{N}$ ); (b) OC from NSF/NCAR C-130 aircraft campaign in ACE-Asia (latitude $25-45^{\circ} \mathrm{N}$ ); (c) $\mathrm{BC}$ from NSF/NCAR GV in HIPPO1 (latitude 20-60 ${ }^{\circ} \mathrm{S}$ ); (d) BC from NSF/NCAR GV in HIPPO1 (latitude $60-67^{\circ} \mathrm{S}$ ). Model and observational data are averaged over $1 \mathrm{~km}$ altitude bins. Simulation data is sampled along the track of both campaigns, with the same month of campaigns but in the year 2005 in terms of monthly mean value.

scheme are found to increase by $\sim 15$ and $\sim 13 \%$ at the same altitude range, with similar results for the condensationcoagulation aging scheme. However, even with the updated aging schemes, the model still significantly underestimates $\mathrm{BC}$ and $\mathrm{OC}$ throughout the $0-6 \mathrm{~km}$ altitude range. We also compared the model simulated $\mathrm{BC}$ vertical profiles in the remote Pacific of the Southern Hemisphere against measurements from the HIPPO1 campaign (Schwarz et al., 2010) (Fig. 10). In contrast to the comparison over the Northern Hemisphere regions, we find that the model results tend to overestimate the BC concentrations (Fig. 10), which is consistent with results of the ensemble models from the AEROCOM intercomparison study (Schwarz et al., 2010). As a consequence, the updated aging schemes would lead to larger model-data discrepancies since they would result in higher $\mathrm{BC}$ concentrations compared to the control run. One exception is for the $2-4 \mathrm{~km}$ altitudes over the $20^{\circ} \mathrm{S}$ and $60^{\circ} \mathrm{S}$ latitude bins (Fig. 10c) where the GEOS-Chem model simulations show reasonable agreement with measured BC. For this specific region, the updated aging schemes would improve the model-data comparison.

\subsection{Effect of the TRIPLE aging scheme on model simulated intercontinental transport of $\mathrm{BC}$ and $\mathrm{OC}$}

The large perturbations to the global distributions of $\mathrm{BC}$ and OC and the improved model simulation results in the Northern Hemisphere with the TRIPLE aging scheme imply that the intercontinental transport of $\mathrm{BC}$ and $\mathrm{OC}$ could be significantly underestimated in previous modeling studies. We examined the potential impacts of the TRIPLE aging scheme on model simulated continental outflow from Asia with sen-
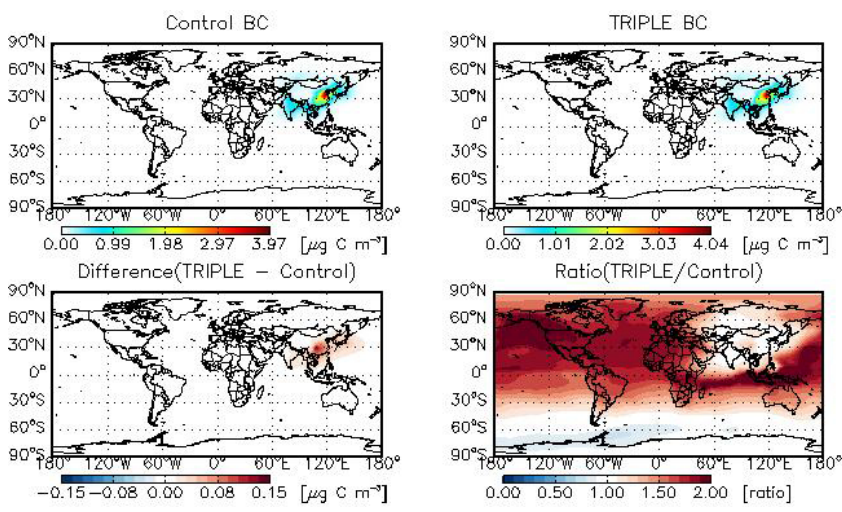

Fig. 11a. Impacts of the TRIPLE aging scheme on model calculated continental outflow of annual mean BC from Asia (the global BC emissions except those over Asia are turned off in the model simulations). (Upper left) Surface BC concentrations from the control run; (upper right) surface $\mathrm{BC}$ concentrations from the sensitivity run with the TRIPLE aging scheme; (lower left) differences between the sensitivity run and control run; (lower right) ratio between the sensitivity run and control run.

sitivity studies where only emissions from the Asian region (as defined in Fig. 1) are turned on in the model. Figure 11a compares the model calculated surface $\mathrm{BC}$ concentrations between the control and TRIPLE aging scheme runs. The largest increases, by up to $0.15 \mu \mathrm{g} \mathrm{Cm}^{-3}$, are found over the source regions, which is consistent with the sensitivity simulation results discussed in Sect. 3.1.

With the TRIPLE aging scheme, the contribution of Asian emission to the annual mean surface $\mathrm{BC}$ (the lowermost layer) in the United States is about $0.006 \mu \mathrm{g} \mathrm{Cm}{ }^{-3}$, which is approximately a factor of 2 higher than that from the control run. Similar results are found for OC aerosols in the surface air (Fig. 11b). The maximum difference between the control and the TRIPLE aging scheme simulation for OC in surface air is approximately $0.2 \mu \mathrm{g} \mathrm{Cm}^{-3}$. The ratio plots in Fig. 11a and $\mathrm{b}$ show that the largest perturbations to surface $\mathrm{BC}$ and $\mathrm{OC}$ are found in areas far away from the source regions. This reflects that the impacts of the updated aging scheme on simulated $\mathrm{BC}$ and $\mathrm{OC}$ become more prominent after long-range transport where the $\mathrm{BC}$ and $\mathrm{OC}$ aerosols experience aging and wet scavenging.

The effects of the TRIPLE aging scheme on long-range transport of carbonaceous aerosols can also be examined through the zonal mean plots (Fig. 11c, d). Compared to the control run, $\mathrm{BC}$ concentrations in the northern middle troposphere double with the TRIPLE aging scheme. Similar results are found for OC. This again reflects that the TRIPLE aging scheme has more implications on areas further away from the source regions. 

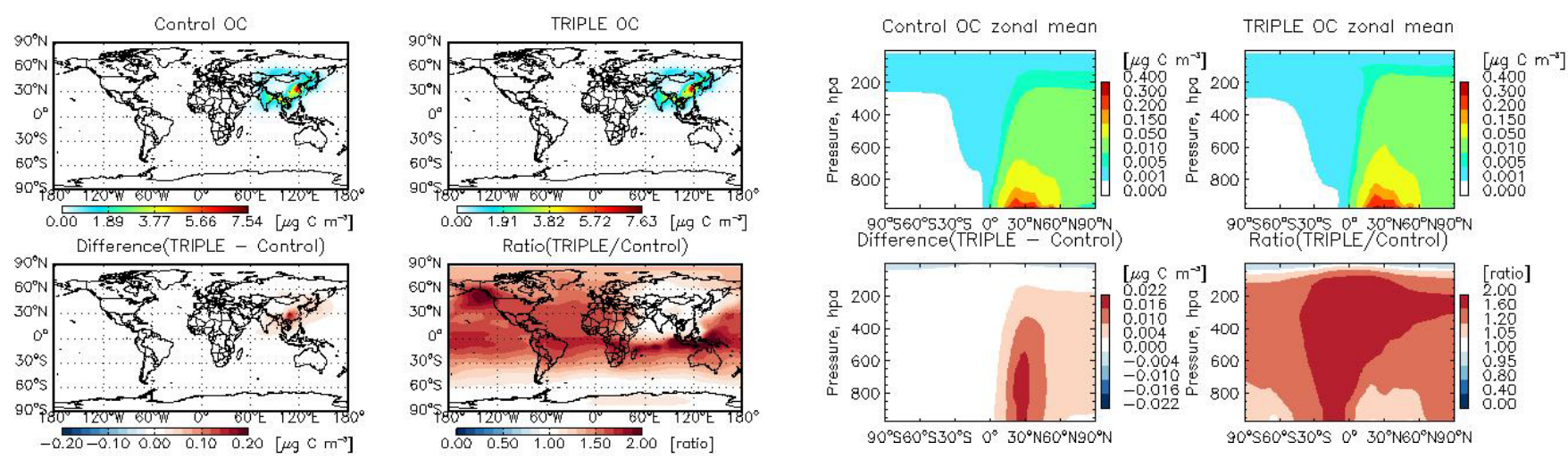

Fig. 11b. Same as Fig. 11a but for OC.

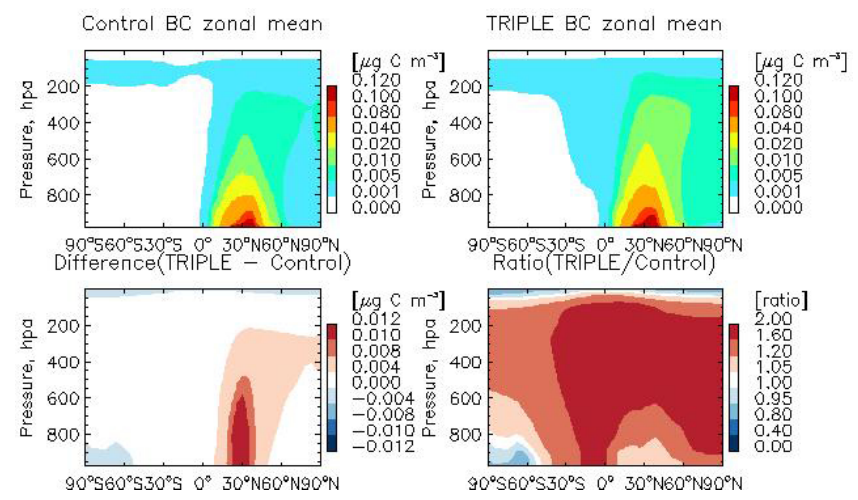

carbonaceous aerosol concentrations more than double compared to the control simulation. The calculated global burden of $\mathrm{BC}$ and $\mathrm{OC}$ increases by 31 and $17 \%$, respectively with the oxidation aging scheme.

The condensation-coagulation aging is affected by the atmospheric concentrations of sulfuric acid (Liu et al., 2011). The longest hydrophobic-to-hydrophilic conversion lifetimes for carbonaceous aerosols are found over the remote regions where the atmospheric concentrations of sulfuric acid are low. The condensation-coagulation aging scheme also has significant impacts on the model simulations of carbonaceous aerosols, with increases in model simulated concentrations of $\mathrm{BC}$ and $\mathrm{OC}$ over tropical regions as well as the Arctic by up to 0.05 and $0.25 \mu \mathrm{g} \mathrm{Cm}{ }^{-3}$, respectively. With the condensation-coagulation aging scheme, global average burdens and lifetimes for BC and OC increase by 25 and $13 \%$, respectively.

In general, the chemical oxidation aging dominates over We have implemented updated aging mechanisms for carbonaceous aerosols in GEOS-Chem by accounting for both the chemical oxidation and the physical condensationcoagulation effects. The chemical aging is affected by local atmospheric environment including $\mathrm{O}_{3}$ concentration and humidity, based on results from chamber studies (Pöschl et al., 2001; Tsigaridis and Kanakidou, 2003). The hydrophobic-to-hydrophilic conversion lifetimes of carbonaceous aerosols due to chemical aging exhibit large spatial and temporal variation with the global average calculated to be 3.1 days, which is much longer than the parameter commonly used in global models. The longest conversion lifetimes are found in the tropical areas such as the Amazon forest, reflecting the low ozone concentration and high humidity there. The conversion lifetime generally decreases with altitude due to increases in ozone concentration and decreases in water vapor concentration.

The oxidation aging mechanism has significant impacts on the model simulations of carbonaceous aerosols, with increases in model simulated concentrations of $\mathrm{BC}$ and $\mathrm{OC}$ by up to 0.16 and $0.67 \mu \mathrm{g} \mathrm{Cm}^{-3}$, respectively. The largest effects are found for the tropical upper troposphere, where the the high latitudes, in particular the polar regions, while the condensation-coagulation aging effects are more important for the tropical and midlatitude continental regions. By accounting for both the chemical and physical aging effects, the global average atmospheric lifetimes of $\mathrm{BC}$ and $\mathrm{OC}$ are found to be 6.31 and 4.70 days respectively, increasing by 9 and $3 \%$ respectively from the control simulations using the old aging scheme. Consequentially, the global atmospheric burdens of $\mathrm{BC}$ and $\mathrm{OC}$ increase by 9 and $3 \%$ respectively compared to the control model runs. In the mean time, large increases in $\mathrm{BC}$ and $\mathrm{OC}$ concentrations (by up to 22 and $15 \%$, respectively) are found in the Southern Hemisphere compared to the control runs.

The combined aging scheme likely overestimates the overall aging rate since it simply linearly sums up the reaction rate coefficients from both oxidation and condensationcoagulation aging mechanisms but does not account for the competition effects of these two aging processes (Croft et al., 2005). Accounting for the competition effects would reduce the aging rate and further increase the atmospheric burdens of $\mathrm{BC}$ and $\mathrm{OC}$. 
Comparisons of the model simulated $\mathrm{BC}$ and $\mathrm{OC}$ against ground-based observational data show that the updated aging schemes improve model performance, especially in the tropical regions or remote areas in the Northern Hemisphere, although significant model underestimates still exist. These improvements could help explain the systematic and persistent low model bias for carbonaceous aerosols in the Northern Hemisphere that have been reported in the literature (e.g., Heald et al., 2011; Bond et al., 2013). However, the updated aging schemes do not help model-observation comparisons in the Southern Hemisphere since model results generally overestimate $\mathrm{BC}$ in these regions. The causes for the model overestimate on BC in the Southern Hemisphere is beyond the scope of this study, but one likely contributing factor is insufficient wet scavenging in the models (Schwarz et al., 2010). On the other hand, the obviously contradicting model performance (overestimates vs. underestimates) in the Southern Hemisphere and Northern Hemisphere (in particular those areas close to the source regions) indicates that there must be multiple factors (such as emission inventories, meteorological fields, wet scavenging parameterization) contributing to the model-data discrepancies for carbonaceous aerosols.

The updated aging schemes also have significant implications for the estimates on model calculated carbonaceous aerosols' continental outflow. Our sensitivity model simulations show that the contributions of Asian emissions to background $\mathrm{BC}$ and $\mathrm{OC}$ in remote regions more than double with the updated aging scheme. The large increases in simulated $\mathrm{BC}$ and $\mathrm{OC}$ in remote regions with the updated aging scheme imply that the intercontinental transport of $\mathrm{BC}$ and $\mathrm{OC}$ and the anthropogenic influences on remote regions (such as the polar regions) could be significantly underestimated in previous modeling studies. There are additional factors (such as the meteorology and wet deposition parameterization used in the models) that could affect the model calculated intercontinental transport but these are not explored in this study.

For easy implementation in global models, we have also tested a simplified aging scheme by tripling the a priori hydrophobic-to-hydrophilic conversion lifetimes for carbonaceous aerosols from 1.15 to 3.45 days. Compared with the control runs, the global average atmospheric lifetimes (and burdens) of BC and OC increase by 43 and $24 \%$, respectively. This simple treatment produces the largest perturbations to the model simulated carbonaceous aerosols and shows the best agreement when compared with observations in the Northern Hemisphere.

There are very limited experimental data available on the aging of carbonaceous aerosols, and the chamber results (Pöschl et al., 2001) used for chemical aging in this study are most representative for BC, but not necessarily for OC. The strong sensitivities of the model simulations of carbonaceous aerosols to the aging schemes indicate that further studies on the aging carbonaceous aerosol are needed to better under- stand the effects of carbonaceous aerosol on climate, atmospheric composition and air quality.

Acknowledgements. This work was supported by US EPA (grant \# R83428601) and NIH (grant \#1 RC1 ES018612). We thank Robert Page at Michigan Tech for his help on programming. We would like to thank people contributing to the multiple datasets including ACE-Asia, HIPPO1, IMPROVE, EMEP, and CAWNET. We thank Joshua Schwarz for help on the HIPPO1 data. We thank the Editor and two anonymous reviewers for their helpful comments.

Edited by: D. Shindell

\section{References}

Balkanski, Y., Myhre, G., Gauss, M., Radel, G., Highwood, E. J., and Shine, K. P.: Direct radiative effect of aerosols emitted by transport: from road, shipping and aviation, Atmos. Chem. Phys., 10, 4477-4489, doi:10.5194/acp-10-4477-2010, 2010.

Bey, I., Jacob, D. J., Yantosca, R. M., Logan, J. A., Field, B. D., Fiore, A. M., Li, Q., Liu, H., Mickley L. J., and M. G. Schultz: Global modeling of tropospheric chemistry with assimilated meteorology: Model description and evaluation, J. Geophys. Res.Atmos., 106, 23073-23095, 2001.

Bond, T. C., Bhardwaj E., Dong, R., Jogani, R., Jung, S., Roden, C., Streets, D. G., and Trautmann, N. M.: Historical emissions of black and organic carbon aerosol from energy-related combustion, 1850-2000, Global Biogeochem. Cy., 21, Gb2018, doi:10.1029/2006gb002840, 2007.

Bond, T. C., Doherty, S. J., Fahey, D. W., Forster, P. M., Berntsen, T., DeAngelo, B. J., Flanner, M. G., Ghan, S., Kärcher, B., Koch, D., Kinne, S., Kondo, Y., Quinn, P. K., Sarofim, M. C., Schultz, M. G., Schulz, M., Venkataraman, C., Zhang, H., Zhang, S., Bellouin, N., Guttikunda, S. K., Hopke, P. K., Jacobson, M. Z., Kaiser, J. W., Klimont, Z., Lohmann, U., Schwarz, J. P., Shindell, D., Storelvmo, T., Warren, S. G., and Zender, C. S.: Bounding the role of black carbon in the climate system: A scientific assessment, J. Geophys. Res.-Atmos., 118, 1-173, doi:10.1002/jgrd.50171, 2013.

Cavalli, F., Facchini, M. C., Decesari, S., Mircea, M., Emblico, L., Fuzzi, S., Ceburnis, D., Yoon, Y. J., O’Dowd, C. D., Putaud, J. P., and Dell'Acqua, A.: Advances in characterization of size-resolved organic matter in marine aerosol over the North Atlantic, J. Geophys. Res.-Atmos., 109, D24215, doi:10.1029/2004JD005137, 2004.

Chin, M., Ginoux, P., Kinne, S., Torres, O., Holben, B. N., Duncan, B. N., Martin, R. V., Logan, J. A., Higurashi, A., and Nakajima T.: Tropospheric aerosol optical thickness from the GOCART model and comparisons with satellite and Sun photometer measurements, J. Atmos. Sci., 59, 461-483, doi:10.1175/15200469(2002)059<0461:taotft>2.0.co;2, 2002.

Chung, S. H. and Seinfeld, J. H.: Global distribution and climate forcing of carbonaceous aerosols, J. Geophys. Res.-Atmos., 107, 4407, doi:10.1029/2001JD001397, 2002.

Colarco, P., da Silva, A., Chin, M., and Diehl, T.: Online simulations of global aerosol distributions in the NASA GEOS-4 model and comparisons to satellite and ground-based 
aerosol optical depth, J. Geophys. Res.-Atmos., 115, D14027, doi:10.1029/2009JD012820, 2010.

Cooke, W. F. and Wilson, J. J. N.: A global black carbon aerosol model, J. Geophys. Res.-Atmos., 101, 19395-19409, doi:10.1029/96JD00671, 1996.

Cooke, W. F., Liousse, C., Cachier, H., and Feichter, J.: Construction of a 1 degrees $\times 1$ degrees fossil fuel emission data set for carbonaceous aerosol and implementation and radiative impact in the ECHAM4 model, J. Geophys. Res.-Atmos., 104, 2213722162, doi:10.1029/1999JD900187, 1999.

Cooke, W. F., Ramaswamy, V., and Kasibhatla, P.: A general circulation model study of the global carbonaceous aerosol distribution, J. Geophys. Res., 107, 4279, doi:10.1029/2001JD001274, 2002.

Croft, B., Lohmann, U., and von Salzen, K.: Black carbon ageing in the Canadian Centre for Climate modelling and analysis atmospheric general circulation model, Atmos. Chem. Phys., 5, 19311949, doi:10.5194/acp-5-1931-2005, 2005.

Easter, R. C., Ghan, S. J., Zhang, Y., Saylor, R. D., Chapman, E. G., Laulainen, N. S., Abdul-Razzak, H., Leung, L. R., Bian, X. D., and Zaveri, R. A.: MIRAGE: Model description and evaluation of aerosols and trace gases, J. Geophys. Res.-Atmos., 109, D20210, doi:10.1029/2004JD004571, 2004.

Fu, T. M., Jacob, D. J., and Heald, C. L.: Aqueous-phase reactive uptake of dicarbonyls as a source of organic aerosol over eastern North America, Atmos. Environ., 43, 1814-1822, doi:10.1016/j.atmosenv.2008.12.029, 2009.

Guenther, A., Karl, T., Harley, P., Wiedinmyer, C., Palmer, P. I., and Geron C.: Estimate of global terrestrial isoprene emissions using MEGAN (Model of Emissions of Gases and Aerosols from Nature), Atmos. Chem. Phys., 6, 3181-3210, doi:10.5194/acp-63181-2006, 2006.

Haywood, J. and Boucher, O.: Estimates of the direct and indirect radiative forcing due to tropospheric aerosols: A review, Rev. Geophys., 38, 513-543, doi:10.1029/1999RG000078, 2000.

Heald, C. L., Jacob, D. J., Turquety, S., Hudman, R. C., Weber, R. J., Sullivan, A. P., Peltier, R. E., Atlas, E. L., de Gouw, J. A., Warneke, C., Holloway, J. S., Neuman, J. A., Flocke, F. M., and Seinfeld, J. H.: Concentrations and sources of organic carbon aerosols in the free troposphere over North America, J. Geophys. Res.-Atmos., 111, D23S47, doi:10.1029/2006JD007705, 2006.

Heald, C. L., Coe, H., Jimenez, J. L., Weber, R. J., Bahreini, R., Middlebrook, A. M., Russell, L. M., Jolleys, M., Fu, T.-M., Allan, J. D., Bower, K. N., Capes, G., Crosier, J., Morgan, W. T., Robinson, N. H., Williams, P. I., Cubison, M. J., DeCarlo, P. F., and Dunlea, E. J.: Exploring the vertical profile of atmospheric organic aerosol: comparing 17 aircraft campaigns with a global model, Atmos. Chem. Phys., 11, 12673-12696, doi:10.5194/acp11-12673-2011, 2011.

Huebert, B., Bertram, T., Kline, J., Howell, S., Eatough, D., and Blomquist, B.: Measurements of organic and elemental carbon in Asian outflow during ACE-Asia from the NSF/NCAR C-130, J. Geophys. Res.-Atmos., 109, D19S11, doi:10.1029/2004JD004700, 2004.

Jacobson, M. Z.: Short-term effects of controlling fossil-fuel soot, biofuel soot and gases, and methane on climate, Arctic ice, and air pollution health, J. Geophys. Res.-Atmos., 115, D14209, doi:10.1029/2009JD013795, 2010.
Jeong, C. H., Hopke, P. K., Kim, E., and Lee, D. W.: The comparison between thermal-optical transmittance elemental carbon and Aethalometer black carbon measured at multiple monitoring sites, Atmos. Environ., 38, 5193-5204, doi:10.1016/j.atmosenv.2004.02.065, 2004.

Kanakidou, M., Seinfeld, J. H., Pandis, S. N., Barnes, I., Dentener, F. J., Facchini, M. C., Van Dingenen, R., Ervens, B., Nenes, A., Nielsen, C. J., Swietlicki, E., Putaud, J. P., Balkanski, Y., Fuzzi, S., Horth, J., Moortgat, G. K., Winterhalter, R., Myhre, C. E. L., Tsigaridis, K., Vignati, E., Stephanou, E. G., and Wilson, J.: Organic aerosol and global climate modeling: a review, Atmos. Chem. Phys., 5, 1053-1123, doi:10.5194/acp-5-1053-2005, 2005.

Koch, D.: Transport and direct radiative forcing of carbonaceous and sulfate aerosols in the GISS GCM, J. Geophys. Res.-Atmos., 106, 20311-20332, doi:10.1029/2001JD900038, 2001.

Koch, D. and Hansen, J.: Distant origins of Arctic black carbon: A Goddard Institute for Space Studies ModelE experiment, J. Geophys. Res.-Atmos., 110, D04204, doi:10.1029/2004JD005296, 2005.

Koch, D., Schulz, M., Kinne, S., McNaughton, C., Spackman, J. R., Balkanski, Y., Bauer, S., Berntsen, T., Bond, T. C., Boucher, O., Chin, M., Clarke, A., De Luca, N., Dentener, F., Diehl, T., Dubovik, O., Easter, R., Fahey, D. W., Feichter, J., Fillmore, D., Freitag, S., Ghan, S., Ginoux, P., Gong, S., Horowitz, L., Iversen, T., Kirkevag, A., Klimont, Z., Kondo, Y., Krol, M., Liu, X., Miller, R., Montanaro, V., Moteki, N., Myhre, G., Penner, J. E., Perlwitz, J., Pitari, G., Reddy, S., Sahu, L., Sakamoto, H., Schuster, G., Schwarz, J. P., Seland, O., Stier, P., Takegawa, N., Takemura, T., Textor, C., van Aardenne, J. A., and Zhao, Y.: Evaluation of black carbon estimations in global aerosol models, Atmos. Chem. Phys., 9, 9001-9026, doi:10.5194/acp-9-9001-2009, 2009.

Kondo, Y., Miyazaki, Y., Takegawa, N., Miyakawa, T., Weber, R. J., Jimenez, J. L., Zhang, Q., and Worsnop, D. R.: Oxygenated and water-soluble organic aerosols in Tokyo, J. Geophys. Res.Atmos., 112, D01203, doi:10.1029/2006JD007056, 2007.

Lapina, K., Heald, C. L., Spracklen, D. V., Arnold, S. R., Allan, J. D., Coe, H., McFiggans, G., Zorn, S. R., Drewnick, F., Bates, T. S., Hawkins, L. N., Russell, L. M., Smirnov, A., O’Dowd, C. D., and Hind, A. J.: Investigating organic aerosol loading in the remote marine environment, Atmos. Chem. Phys, 11, 8847-8860, doi:10.5194/acp-11-8847-2011, 2011.

Liao, H., Henze, D. K., Seinfeld, J. H., Wu, S. L., and Mickley, L. J.: Biogenic secondary organic aerosol over the United States: Comparison of climatological simulations with observations, J. Geophys. Res.-Atmos., 112, D06201, doi:10.1029/2006JD007813, 2007.

Liousse, C., Penner, J. E., Chuang, C., Walton, J. J., Eddleman, H., and Cachier, H.: A global three-dimensional model study of carbonaceous aerosols, J. Geophys. Res.-Atmos., 101, 1941119432, doi:10.1029/95JD03426, 1996.

Liu, H. Y., Jacob, D. J., Bey, I., and Yantosca, R. M.: Constraints from pb-210 and Be-7 on wet deposition and transport in a global three-dimensional chemical tracer model driven by assimilated meteorological fields, J. Geophys. Res.-Atmos., 106, 12109-12128, doi:10.1029/2000JD900839, 2001.

Liu, J., Mauzerall, D. L., Horowitz, L. W., Ginoux, P., and Fiore, A. M.: Evaluating intercontinental transport of 
fine aerosols: (1) Methodology, global aerosol distribution and optical depth, Atmos. Environ., 43, 4327-4338, doi:10.1016/j.atmosenv.2009.03.054, 2009.

Liu, J., Fan, S., Horowitz, L. W., and Levy, H.: Evaluation of factors controlling long-range transport of black carbon to the Arctic, J. Geophys. Res.-Atmos., 116, D04307, doi:10.1029/2010JD015145, 2011.

Liu, X., Penner, J. E., and Herzog, M.: Global modeling of aerosol dynamics: model description, evaluation, and interactions between sulfate and nonsulfate aerosols, J. Geophys. Res.-Atmos., 110, D18206, doi:10.1029/2004JD005674, 2005.

Lohmann, U., Feichter, J., Penner, J., and Leaitch, R.: Indirect effect of sulfate and carbonaceous aerosols: A mechanistic treatment, J. Geophys. Res.-Atmos., 105, 12193-12206, doi:10.1029/1999JD901199, 2000.

Mann, G. W., Carslaw, K. S., Ridley, D. A., Spracklen, D. V., Pringle, K. J., Merikanto, J., Korhonen, H., Schwarz, J. P., Lee, L. A., Manktelow, P. T., Woodhouse, M. T., Schmidt, A., Breider, T. J., Emmerson, K. M., Reddington, C. L., Chipperfield, M. P., and Pickering, S. J.: Intercomparison of modal and sectional aerosol microphysics representations within the same 3-D global chemical transport model, Atmos. Chem. Phys., 12, 4449-4476, doi:10.5194/acp-12-4449-2012, 2012.

Maria, S. F., Russell, L. M., Gilles, M. K., and Myneni, S. C. B.: Organic aerosol growth mechanisms and their climate-forcing implications, Science, 306, 1921-1924, doi:10.1126/science.1103491, 2004.

Meskhidze, N., Xu, J., Gantt, B., Zhang, Y., Nenes, A., Ghan, S. J., Liu, X., Easter, R., and Zaveri, R.: Global distribution and climate forcing marine organic aerosol: 1. Model improvements and evaluation, Atmos. Chem. Phys., 11, 11689-11705, doi:10.5194/acp-11-11689-2011, 2011.

Middlebrook, A. M., Murphy, D. M., and Thomson, D. S.: Observations of organic material in individual marine particles at Cape Grim during the First Aerosol Characterization Experiment (ACE 1), J. Geophys. Res.-Atmos., 103, 16475-16483, doi:10.1029/97JD03719, 1998.

Park, R. J., Jacob, D. J., Chin, M., and Martin, R. V.: Sources of carbonaceous aerosols over the United States and implications for natural visibility, J. Geophys. Res.-Atmos., 108, 4355, doi:10.1029/2002JD003190, 2003.

Park, R. J., Jacob, D. J., Field, B. D., Yantosca, R. M., and Chin, M.: Natural and transboundary pollution influences on sulfate-nitrate-ammonium aerosols in the United States: Implications for policy, J. Geophys. Res.-Atmos., 109, D15204, doi:10.1029/2003JD004473, 2004.

Pierce, J. R., Chen, K., and Adams, P. J.: Contribution of primary carbonaceous aerosol to cloud condensation nuclei: processes and uncertainties evaluated with a global aerosol microphysics model, Atmos. Chem. Phys., 7, 5447-5466, doi:10.5194/acp-75447-2007, 2007.

Pöschl, U., Letzel, T., Schauer, C., and Niessner, R.: Interaction of ozone and water vapor with spark discharge soot aerosol particles coated with benzo[a]pyrene: $\mathrm{O}_{3}$ and $\mathrm{H}_{2} \mathrm{O}$ adsorption, benzo[a]pyrene degradation, and atmospheric implications, J. Phys. Chem. A., 105, 4029-4041, doi:10.1021/jp004137n, 2001.

Ramanathan, V. and Carmichael, G.: Global and regional climate changes due to black carbon, Nat. Geosci., 1, 221-227, doi:10.1038/ngeo156, 2008.
Riemer, N., Vogel, H., and Vogel, B.: Soot aging time scales in polluted regions during day and night, Atmos. Chem. Phys., 4, 1885-1893, doi:10.5194/acp-4-1885-2004, 2004.

Schulz, M., Textor, C., Kinne, S., Balkanski, Y., Bauer, S., Berntsen, T., Berglen, T., Boucher, O., Dentener, F., Guibert, S., Isaksen, I. S. A., Iversen, T., Koch, D., Kirkevag, A., Liu, X., Montanaro, V., Myhre, G., Penner, J. E., Pitari, G., Reddy, S., Seland, O., Stier, P., and Takemura, T.: Radiative forcing by aerosols as derived from the AeroCom present-day and pre-industrial simulations, Atmos. Chem. Phys, 6, 5225-5246, doi:10.5194/acp-65225-2006, 2006.

Schwarz, J. P., Spackman, J. R., Gao, R. S., Watts, L. A., Stier, P., Schulz, M., Davis, S. M., Wofsy, S. C., and Fahey, D. W.: Global-scale black carbon profiles observed in the remote atmosphere and compared to models, Geophys. Res. Lett., 37, L18812, doi:10.1029/2010GL044372, 2010.

Spracklen, D. V., Arnold, S. R., Sciare, J., Carslaw, K. S., and Pio, C.: Globally significant oceanic source of organic carbon aerosol, Geophys. Res. Lett., 35, L12811, doi:10.1029/2008GL033359, 2008.

Tsigaridis, K. and Kanakidou, M.: Global modeling of secondary organic aerosol in the troposphere: a sensitivity analysis, Atmos. Chem. Phys., 3, 1849-1869, doi:10.5194/acp-3-1849-2003, 2003.

US Environmental Protection Agency (EPA): Report on air quality in nonattainment areas for 2003-2005 covering ozone, particulate matter, carbon monoxide, sulfur dioxide, nitrogen dioxide, and lead, Washing, D. C., http://www.epa.gov/air/airtrends/pdfs/ 20070214_aq_na_2003-2005.pdf, 2007.

van der Werf, G. R., Randerson, J. T., Giglio, L., Collatz, G. J., Kasibhatla, P. S., and Arellano Jr., A. F.: Interannual variability in global biomass burning emissions from 1997 to 2004, Atmos. Chem. Phys., 6, 3423-3441, doi:10.5194/acp-6-3423-2006, 2006.

Vignati, E., Karl, M., Krol, M., Wilson, J., Stier, P., and Cavalli, F.: Sources of uncertainties in modelling black carbon at the global scale, Atmos. Chem. Phys., 10, 2595-2611, doi:10.5194/acp-102595-2010, 2010.

Wang, Q., Jacob, D. J., Fisher, J. A., Mao, J., Leibensperger, E. M., Carouge, C. C., Le Sager, P., Kondo, Y., Jimenez, J. L., Cubison, M. J., and Doherty, S. J.: Sources of carbonaceous aerosols and deposited black carbon in the Arctic in winter-spring: implications for radiative forcing, Atmos. Chem. Phys., 11, 12453 12473, doi:10.5194/acp-11-12453-2011, 2011.

Wang, Y. H., Jacob, D. J., and Logan, J. A.: Global simulation of tropospheric $\mathrm{O}_{3}-\mathrm{NO}_{\mathrm{X}}$-hydrocarbon chemistry 1. Model formulation, J. Geophys. Res.-Atmos., 103, 10713-10725, doi:10.1029/98JD00158, 1998.

Wesely, M. L. : Parameterization of surface resistances to gaseous dry deposition in regionalscale numerical-models, Atmos. Environ., 23, 1293-1304, doi:10.1016/0004-6981(89)90153-4, 1989.

Zhang, X. Y., Wang, Y. Q., Zhang, X. C., Guo, W., and Gong, S. L.: Carbonaceous aerosol composition over various regions of China during 2006, J. Geophys. Res., 113, D14111, doi:10.1029/2007JD009525, 2008. 